\title{
COMPORTAMENTO DE HÍBRIDOS DE MILHO TARDIO, PRECOCE E SUPERPRECOCE, NA ÉPOCA DE "SAFRINHA", SUBMETIDOS A DIFERENTES NIVEIS DE NITROGÊNIO
}

\author{
Ana Rita de Moraes Brandão Brito \\ Engenheira Agro̊noma
}

Orientador: Prof. Dr. Antonio Luiz Fancelli

\begin{abstract}
Dissertaçăo apresentada à Escola Superior de Agricultura "Luiz de Queiroz", da Universidade de Săo Paulo, para obtençăo do Titulo de Mestre em Agronomia, Área de concentraçăo: Fitotecnia
\end{abstract}

PIRACICABA

Estado de São Paulo - Brasll

Outubro - 1995 


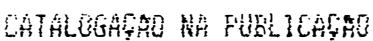

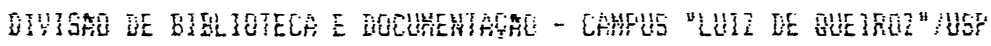

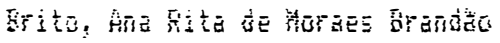

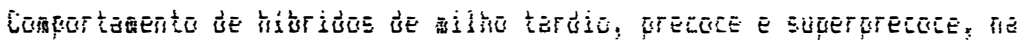

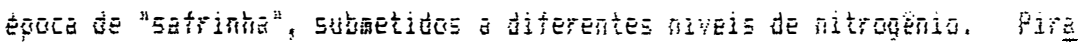
Eicaba, 1975 .

70. ilus.

DiEs. 佉EELTE - ESALE

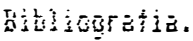

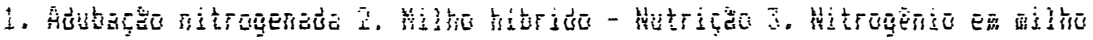

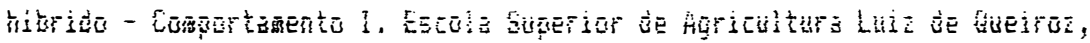
fícacicaté

(ID) 


\section{COMPORTAMENTO DE HÍBRIDOS DE MILHO TARDIO, PRECOCE E SUPERPRECOCE, NA ÉPOCA DE "SAFRINHA", SUBMETIDOS A DIFERENTES NIVEIS DE NITROGÉNIO}

Ana Rita de Moraes Brandăo Brito

Aprovada em: 11/10/95

Comissåo julgadora:

Prof. Dr. Antonio Luiz Fancelli

ESALQIUSP

Prof. Dr. Silvio Moure Cicero

ESALQ/USP

Dr. Frederico Ozanan Machado Durães

EMBRAPACNPMS

Prof. Dr. Antonio Luiz Fancelli

-Orientador- 
A meus pais Luiz Paulo e

Maria Isaura e irmãos

ofereço

A meu esposo Gilberto e

a minha filha Luana (in memoriam)

dedico 


\section{AGRADECIMENTOS}

- Ao professor Dr. Antonio Luiz Fancelli, pela orientaçăo, amizade e pelo profissionalismo demonstrado.

Aos Engenheiros Agrônomos Frederico Ozanan Machado Duråes e Milciades Gadelha de Lima, pelo apoio na conduçăo do trabalho.

Ao colega Milton Cezar Ribeiro do Departamento de Ciências Florestais da ESALQ/USP, pelos auxilios nas análises estatísticas.

. Aos professores e funcionários do Departamento de Agricultura da ESALQUSP, pela colaboração prestada.

Aos estagiários Frederico Lopes Peres e Guilherme Juliano Braga da Rosa pela ajuda prestada na coleta de dados.

A Ampresa Pernambucana de Pesquisa Agropecuária - IPA, pela oportunidade concedida.

A Coordenaçăo de aperfelçoamento de pessoal de nivel superior (CAPES), pelo suporte financeiro.

AOs funcionários da biblioteca central da ESALQ, USP, pela amizade e colaboração.

A ESALQUSP pelo curso oferecido.

. Aos colegas de turma, pela amizade e convivência.

A todos que colaboraram para a realizaçăo deste trabalho. 


\section{SUMÁRIO}

Página

LISTA DE TABELAS

viii

LISTA DE FIGURAS

$x$

RESUMO

xii

SUMMARY

xiv

1. INTRODUÇAO

01

2. REVISAO DE LITERATURA

03

2.1. Cuttivo do mitho safrinha

03

2.2. Influência do nitrogênio no periodo de enchimento do grăo

07

2.3. Período de enchimento do grão

3. MATERIAL E METTODOS

3.1. Localização

3.2. Dados meteorológicos

3.3. Cultivares utilizados

20

3.4. Tratamentos

20

3.5. Procedimento experimental e colheita

3.6. Caracteres avaliados

3.6.1. Caracteres agronómicos

3.6.2. Componentes da produçăo 
4. RESULTADOS 29

4.1. Avaliações de campo 29

4.1.1. Altura de planta (ALT) 29

4.1.2. Indice de área foliar (IAF) 30

4.1.3. Graus-dia 31

4.2. Componentes da produção 32

4.2.1. Número de espigas por planta (NES) 32

4.2.2. Comprimento da espiga (CES) 33

4.2.3. Peso de espiga (PES) 34

4.2.4. Produção de grão (PG) 35

4.2.5. Acúmulo de matéria seca do grão 36

5. DISCUSSÃO

5.1. Crescimento de planta 51

5.1.1. Altura de plantas 51

5.1.2. Indice de área foliar 52

5.1.3. Somatória calórica 53

5.2. Componemtes da produção 54

5.2.1. Acúmulo de matéria seca dos grāos 56

6. CONCLUSÕES 58

REFERENCIAS BIBLIOGRAFICAS 
7.1. Apêndice 1. Dados meteorológicos

7.2. Apêndice II Caracteres agronômicos estudados (valores médios)

7.3. Apêndice III. Valores médios da matéria seca do gräo em cultivar de milho de ciclo normal (XL 380)

7.4. Apêndice $W$. Valores médios da matéria seca do grão em cultivar de milho de ciclo precoce (BR 201)

7.5. Apêndice $V$. Valores médios da matéria seca do grão em cultivar de milho de ciclo superprecoce (P 3072) 


\section{LISTA DE TABELAS}

Página

Tabela 1: Caracteristicas dos cultivares de milho.

Tabela 2: Resultados da análise química do solo

Tabela 3: Esquema de adubaçăo nitrogenada empregada no experimento de milho safrinha. Piracicaba, SP.

Tabela 4: Graus-dia, para os três cultivares de milho de diferentes ciclos. Piracicaba, SP. 1993.

Tabela 5: Análise de variância (quadrado médio) dos resultados, referentes aos parâmetros avaliados, de trés cultivares de milho de diferentes ciclos vegetativos $(c 1=$ normal, $c 2=$ precoce e $\mathrm{c} 3=$ superprecoce) em quatro niveis de nitrogênio $(N O=O \mathrm{~kg} / \mathrm{ha}, \mathrm{N} 1=50 \mathrm{~kg} / \mathrm{ha}, \mathrm{N} 2=100 \mathrm{~kg} / \mathrm{ha}$ e $\mathrm{N} 3=150$ kg(ha), média de três repeti̧̧̋̃es. Piracicaba, SP. 1993.

Tabela 6. Média referente às caracteristicas estudadas, obtidas para os três cultivares de milho de diferentes ciclos vegetativos ( $c 1=$ normal,$c 2=$ precoce e $c 3=$ superprecoce). Piracicaba, SP. 1993.

Tabela 7: Média referente as características estudadas, obtidas para os niveis de nitrogenio $(\mathrm{NO}=\mathrm{O} \mathrm{kg} / \mathrm{ha}, \mathrm{N} 1=50 \mathrm{~kg} / \mathrm{ha}, \mathrm{N} 2=100$ $\mathrm{kg} / \mathrm{ha}$ e N3 = $150 \mathrm{~kg} / \mathrm{ha})$. Piracicaba, SP. 1993. 
Tabela 8: Variação da matéria seca do grăo (média de seis plantas) em $\mathrm{g} / \mathrm{m}^{2}$ de cultivares de milho de diferentes ciclos e quatro niveis de nitrogénio. Piracicaba, SP. 1993. 


\section{LISTA DE FIGURAS}

Página

Figura 1. Representaçăo gráfica da equaçăo de regressăo que expressa os efeitos de cultivares e doses de nitrogénio sobre a altura.

Figura 2. Representação gráfica da equação de regressão que expressa os efeitos de cultivares e doses de nitrogênio sobre indice de área foliar

Figura 3. Representação gráfica da equação de regressão que expressa os efeitos de cultivares e doses de nitrogênio sobre o número médio de espiga por planta

Figura 4. Representaçăo gráfica da equaçăo de regressăo que expressa os efeitos de cultivares e doses de nitrogénio sobre o comprimento da espiga

Figura 5. Representaçăo grâfica da equação de regressão que expressa os efeitos de cultivares e doses de nitrogênio sobre o peso da espiga

Figura 6. Representação gráfica da equaçăo de regressã̃o que expressa os efeitos de cultivares e doses de nitrogênio sobre a produçăo

Figura 7. Acúmulo da matéria seca do grăo em cultivar de mitho de ciclo normal $(c 1=X L 380)$ e quatro niveis de nitrogênio. Piracicaba, SP. 1993. 
Página

Figura 8. Acúmulo da matéria seca do grão em cultivar de milho de ciclo precoce $(c 2=B R 201)$ e quatro niveis de nitrogénio. Piracicaba, SP. 1993.

Figura 9. Acúmulo da matéria seca do grăo em cultivar de milho de ciclo superprecoce $(c 3=P 3072)$ e quatro niveis de nitrogênio. Piracicaba, SP. 1993. 


\title{
COMPORTAMENTO DE HÍBRIDOS DE MILHO TARDIO, PRECOCE E SUPERPRECOCE, NA ÉPOCA DE "SAFRINHA", SUBMETIDOS A DIFERENTES NIVEIS DE NITROGÊNIO
}

\author{
Autora: Ana Rita de Moraes Brandăo Brito \\ Orientador: Prof. Dr. Antonio Luiz Fancelli
}

\section{RESUMO}

Entre as altemativas de culturas temporárias, a cultura do milho "safrinha" vem apresentando bom resultado económico nos últimos anos, em decorrência do comportamento favorável do clima e o baixo custo de produçăo. Os objetivos do presente trabaiho referem-se à avaliaçăo do comportamento de hibridos de milho de ciclos diferentes, semeados na época de "safrinha", bem como ao estudo do periodo de duraçăo do enchimento de grăos, sob a influência de diferentes niveis de nitrogênio.

- experimento foi conduzido em área pertencente ao Departamento de Agricultura da Escola Superior de Agricultura "Luiz de Queiroz", da Universidade de São Paulo, no periodo de janeiro a junho de 1993 , em solo 
classificado como Terra Roxa Estruturada eutrófica. Foram avaliados, três cultivares de milho de diferentes ciclos, ou seja, tardio, precoce e superprecoce, e quatro doses de nitrogênio, sendo $0,50,100$ e $150 \mathrm{~kg} / \mathrm{ha}$ de $\mathrm{N}$.

A coleta de dados foi iniciada a partir do florescimento. Para os caracteres agronômicos avaliaram-se: índice de área foliar, altura da planta e graus-dia, enquanto que para os caracteres de produção avaliaram-se: número de espigas por planta, comprimento da espiga, peso da espiga, produção de grăos e matéria seca do grâo.

Pela análise dos resultados concluiu-se que: a) Para a semeadura do milho na época de "safrinha", a interaçåo genótipo-ambiente, assume acentuada importância; b) Na "safrinha", híbridos que apresentam longo periodo de enchimento de grăos e acúmulo uniforme de matéria seca no período, proporcionam melhor rendimento e produção; c) A adubação nitrogenada em cobertura, em condiçōes de "safrinha" năo resulta em substancial acréscimo no indice de área foliar e no rendimento dos híbridos estudados, sobretudo para o cultivar superprecoce. 


\section{BEHAVIOR OF LATE, EARLY, AND VERY EARLY MAIZE HYBRIDS IN "SAFRINHA"SEASON SUBMITTED TO DIFFERENT NITROGEN LEVELS}

Author: Ana Rita de Moraes Brandāo Brito Adviser: Prof. Dr. Antonio Luiz Fancelli

\section{SUMMARY}

Among temporary crop altematives the "safrinha" maize culture has presented good economical results in the past years as a consequence of the favorable climatic behavior and low production cost. The goal of this work is to evaluate the behavior of different cycle maize mybrids, sown during the "safrinha" season as well as to study the duration of the grain filling period under the influence of different nitrogen levels.

The experiment was conducted within an area of the Agricutture Department of the Escola Superior de Agricultura "Luiz de Queiroz", University of Săo Paulo, from January to June, 1993, in an Eutrophic Structured "Terra Roxa" soil. Three maize cultivars from different cycles, namely, late, early, 
and very earty, and four nitrogen doses at $0,50,100$ and $150 \mathrm{~kg} / \mathrm{ha}$ of $\mathrm{N}$ were evaluated.

Data began to be collected at flowering. The leaf area index, plant height, and degree-days were evaluated for agricultural features while number of ears per plant, ear length, ear weight, grain production, and dry matter of grain were evaluated for production features.

The analysis of results showed that the genotype-emvironment interaction for maize sowing during the "safrinha" season assumes a distinctive importance; During the "safrinha, long grain filling periods and uniform accumulation of dry matter during the period provide better yielding and production; Nitrogen manuring on topsoll under "safrinha" conditions does not represent a significant increase in the leaf area index nor in the yielding of the studied mybrids, especially for the very earty cultivar. 


\section{INTRODUÇÃO}

A cultura do milho é uma das mais difundidas no mundo. No Brasil, o milho é plantado de norte a sul do País, ocupando a maior área cultivada, ou seja aproximadamente 13 milhões de hectares.

Apesar de apresentar elevado potencial produtivo, o rendimento da cultura no Brasil é considerado baixo devido, principalmente, a \% extrema dificuldade evidenciada no processo de difusão e adoção de tecnologias mais avançadas dentro dessa cultura. Entre as tecnologias essenciais destaca-se a semeadura em épocas mais adequadas, escolha de cultivares mais adaptados às condições regionais, uso de sementes melhoradas, emprego de populaçăo correta de plantas e uso adequado de corretivos e fertilizantes, entre outras, com o intuito de proporcionar condiçס̄es que permitam à cultura manifestar todo seu potencial produtivo (FANCELLI, 1986). 
Uma das vantagens que a agricultura brasileira vem oferecendo, ultimamente, é a possibilidade da produção de mais de uma safra de milho por ano, ou seja, uma primeira que abrange todas as regioes do pais e corresponde a $95 \%$ do total e uma segunda, que corresponde aos restantes $5 \%$ e que vem crescendo nos ültimos anos. Essa segunda safra, que vem sendo convencionada de milho "safrinha", obteve produção estimada em 2,4 milhø̋es de toneladas no ano agrícola de 1992/93, de acordo com a Companhia Nacional de Abastecimento (TSUNECHIRO, 1994).

No entanto, por se tratar de um sistema de exploraçăo relativamente recente, ainda não existem informaçర̋es técnicas suficientes para explorar todo o seu potencial produtivo. Por isso, há necessidade de conhecimentos básicos e indispensáveis, tais como: época de semeadura, recomendação de cultivares, espaçamento, densidade de plantas e adubação.

Visando discutir as diferenças de comportamento entre diferentes híbridos e épocas de semeadura, uma considerada atenção tem sido dispensada à produçăo de grăos, enquanto que o conhecimento da duraçăo do periodo de formaçăo do grăo tem sido amplamente ignorado.

Assim, O objetivo do presente trabalho refere-se à avaliaçăo do comportamento de hibridos de milho de ciclos diferentes semeados na época de safrinha, bem como zo estudo do periodo de duração do enchimento de grăos, sob a influência de diferentes niveis de nitrogênio. 


\section{REVISÃO DE LITERATURA}

\subsection{Cultivo do milho safrinha}

Entre as altemativas de cutturas temporárias, a cultura do milho "safrinha", apesar do atto risco de produção em relação às condições climáticas, vem apresentando bom resultado econômico nos últimos anos, em decorrência do comportamento favorável do clima e o baixo custo de produção.

Iniciada há mais de quinze anos, a "safrinha"de milho tem alcançado aumentos expressivos nos últimos anos, ocupando mais de um milhão de hectares em 1993, conforme dados da Companhia Nacional de Abastecimento (CONAB). Embora considerando, ainda, certo grau de riscos e incertezas, característico da maioria dos cultivos de entressafra, a cultura do milho, em sucessão às de primavera-verão, e que vem sendo convencionada de 
milho "safrinha", permite a colheita de uma segunda safra no mesmo ano agricola. Também, protege o solo durante o outono-inverno; proporciona melhor utuilização da terra, da maquinaria agricola e da măo-de-obra e, ainda, possibilita uma rentabilidade adicional ao produtor rural, através da produçāo de forragem, grăo elou milho verde (OLIVEIRA, 1994). Além disso, sua colheita coincide com a entressafra de oferta do produto, tomando-se, assim, o mercado plenamente comprador e com maiores oportunidades de o produtor obter preços mais compensadores.

O grande incremento da área da semeadura extemporânea, ficou por conta da Regiăo Centro-Sul, destacando-se os Estados do Paraná, Săo Paulo e os Estados Centrais. A medida que a atividade foi se tomando economicamente atrativa, muitos agricultores, mormente os de médio e grande porte, passaram a investir na lavoura, iniciando pela aquisição de sementes melhoradas, adubação (principalmente nitrogênio em cobertura), controle químico de pragas e plantas daninhas, entre outras. Face a essa nova realidade de cultivo, a pesquisa oficial passou a ser solicitada no fornecimento de dados experimentais que embasassem melhor as informaçőes a serem transferidas aos agricultores, uma vez que nåo havia conhecimentos básicos e indispensáveis, tais como: época de semeadura, recomendaçăo de cultivares, espaçamento e densidade de plantas, adubaçāo, ocorrência de pragas a doenças, entre outros (GERAGE \& BIANCO, 1987).

Alguns trabalhos do cultivo de milho "safrinha", com relação a época de semeadura, densidades de plantas e recomendaçăo de cultivares, 
foram conduzidos com o objetivo de minimizar os riscos que são mais acentuados nesse perfodo.

A avaliaçăo de cultivares de milho possibilita a identificaçăo e caracterização de cultivares para uma determinada região elou época de plantio. Assim sendo, foram conduzidos por SAWAZAKI et al. (1994), em São Paulo, um ensaio de adaptaçăo e estabilidade de produçåo, onde verificaram altos rendimentos de grão, com rendimento acima de $4.000 \mathrm{~kg} / \mathrm{ha}$ nas cidades de Votuporanga (5.532 kg/ha) e Ituverava $(4.110 \mathrm{~kg} / \mathrm{ha})$ e que as condiçós climáticas, durante o ensaio foram mais favoráveis a produçăo do milho. Com o mesmo objetivo ESTEVES et al. (1994) verificaram que os cultivares de milho testados produziram pouco, em média $2491 \mathrm{~kg} / \mathrm{ha}$, devido ao estresse hidrico ocorrido, principalmente, após o florescimento.

Outros ensaios foram conduzidos em vários locais no Vale do Paranapanema, em Săo Paulo, por DUARTE et al. (1994), os quais verificaram que os cultivares mais adaptados e estáveis em todos os locais foram os de ciclo médio e precoce.

Estudos realizados com o intuito de observar o efeito de épocas de semeadura sobre o rendimento final e identificar o ciclo do cultivar mais adequado para a época da safrinha, foram realizados por OLIVEIRA et al. (1994), no Estado do Mato Grosso. Constou da avaliaçăo, seis cultivares de diferentes ciclos (dois de ciclo superprecoce, dois de ciclo precoce e dois de ciclo normal), em cinco épocas de semeadura (10 de fevereiro a 11 de abril), a intervalos de 15 dias. Os resultados foram promissores, com rendimento de grăos 
correspondente a 3301 e $3590 \mathrm{Kg} / \mathrm{ha}$, para as épocas de 10 e 25/02/92, respectivamente. Concluiram, os autores que os cultivares de ciclo superprecoce e precoce mostraram melhor desempenho em relaçăo às de ciclo normal, verificando assim, que a época de semeadura afeta, principalmente, o cicio do cultivar e o rendimento de grăo. Em outro estudo, TEIXEIRA (1994) verificou em Dourados, MS, que os rendimentos médios de grãos obtidos nas diferentes épocas foram de 2652,2420 e $2175 \mathrm{Kg} / \mathrm{ha}$, respectivamente para a semeadura de janeiro, fevereiro e março e que os cultivares que apresentaram os maiores rendimentos de grăos foram os cultivares de ciclo médio, incluindo o BR 201.

Trabalho recente, referente a densidade de plantas e a identificaçāo do ciclo de cultivares, mais adequado ao cultivo de milho na entressafra, foi realizado por DURAES (1993). Observou o autor que 0 rendimento de grãos variou entre os cultivares e entre as densidades de plantas utilizadas, sendo, significativamente superior nas maiores densidades de cultivos, para os três cultivares de diferentes ciclos vegetativos, ou seja, normal, precoce e superprecoce. Concluiu, ainda que as condiçбes ambientais de cultivo de safrinha sấo subótimas para o desenvolvimento do milho, principalmente para os cultivares com caracteristicas e comportamento de precocidade acentuada. Ainda, relata que para o cultivo de safrinha, deve-se dar preferência a genótipos que tenham larga capacidade de dreno e que acumulem rapidamente matéria seca em seus orgãos, continuando a acumular, paralelamente ao enchimento de grăos, matéria seca total. 


\subsection{Influência do nitrogénio no periodo de enchimento do grão}

O nitrogênio, na agricultura modema, tem sido um dos fatores mais limitantes no rendimento de grão. E o elemento que se encontra em maior quantidade na matéria seca total da planta de milho e, portanto, toma-se necessário provê-la em doses adequadas durante o perlodo de desenvolvimento da cultura para a obtençăo de altas produçōes de grãos (MEDEIROS \& SILVA, 1975).

- conhecimento do acúmulo de matéria seca, por uma cultura, possibilita melhor entendimento dos fatores relacionados á nutrição mineral e, consequentemente, da adubação.

O primeiro trabalho expressivo sobre acúmulo e distribuiçăo de matéria seca e nutrientes em relação ao ciclo da planta de milho fol realizado por SAYRE (1948), que observou ser o crescimento do milho funçăo linear do tempo. A curva do peso de matéria seca da planta é ligeiramente sigmóide e a acumulaçăo do nitrogénio aumenta nos tecidos verdes, para posteriormente sofrer intensa translocação para os grăos, cessando a absorção, aproximadamente, aos trés meses de idade da planta, cujo ponto de máximo ocorre no embonecamento (espigas com estilo-estigmas receptivos). 
HANWAY (1962) estudando a acumulaçāo progressiva da matéria seca em plantas de milho, verificou que as variações na fertilidade do solo produziram diferentes niveis de acumulação. Notou, no entanto, que as mesmas năo influiram notoriamente nas proporções relativas das diferentes partes da planta.

Estudos sobre a duraçăo do perfodo compreendido entre o florescimento até a maturidade fisiológica e a taxa de fertilizante sugerem diferenças entre hibridos de milho, e época de plantio.

Estudos desemolvidos por Lee 1 citado por TSAl et al. (1984) indicam que altos niveis de fertilizante nitrogenado prolongam e aumentam a taxa de enchimento de grão, quando comparados com baixo suprimento desse elemento.

Todavia, PEASLEE (1977) nåo verificou efeito do adubo nitrogenado sobre a duraçăo do periodo de enchimento de grão. Ainda, em outro estudo PEASLEE et al. (1971) observaram que para semeadura de milho mais cedo, as dosagens de fósforo tiveram pouco efeito sobre o período de enchimento de grăo, ao contrário do que aconteceu para o plantio mais tardio. Para as duas datas de plantio, as dosagens de potássio foram positivamente correlacionadas com a duraçăo do periodo de enchimento de grăo.

IER, T.C. The relationship of nitrogen gint and Kernel sink strength on dry matter accumulation in zea mays $I$. West Iafayette, 1981, 161p. (Ph D. Purdue University). 
A resposta do milho à adição crescente de adubo nitrogenado difere consideravelmente. Alguns hibridos experimentais mostraram aumento no teor de proteína efou produçăo de grăo, com o aumento na taxa de nitrogênio (WARREN et al., 1980).

BALKO \& RUSSELL (1980) relataram que alguns cultivares de milho congênitos năo mostraram nenhuma resposta, enquanto que outros apresentaram respostas linear ou quadrática à produção, com o aumento da adubaçăo nitrogenada. Os mesmos autores tambem observaram que em alguns genótipos de milho, a resposta do adubo nitrogenado foi manifestada através do aumento do número de espiga, comprimento da espiga por planta ou número de grăos. Da mesma forma, KAMPRATH et al. (1982) obtiveram uma correlação linear entre taxa de adubo nitrogenado e nümero de espiga, em populações hibridas melhoradas, obtidas através da seleção recorrente.

Estudos realizados por TSAl et al. (1984) demonstraram que a produção de grãos em milho é variável entre os cultivares, em função da resposta à adubaçăo nitrogenada. Acrescentam, ainda, que a produçăo de grăo é afetada por vários fatores: a) diferença na taxa e duraçăo de enchimento de grăos; b) na taxa de sintese da zeina e c) diferenças na capacidade dos hibridos em absorver o nitrogênio após a emissão dos estilo-estigmas da espiga.

Os acréscimos observados no rendimento de grăos em função da aplicação do nitrogênio, tem sido atribuido ao melhor desenvolvimento das plantas, expresso pelo incremento da área foliar (MEDEIROS \& SILVA, 1975; PEREIRA et al. 1981). 


\subsection{Periodo de enchimento de grăo}

O periodo compreendido entre a fertilização e a maturidade fisiológica do milho é caracterizado por trés fases distintas do desemvolvimento do grăo (JOHNSON \& TANNER, 1972). A primeira, fase corresponde ao período durante o qual a divisăo celular é predominante, segundo REDDY \& DAYNARD (1983) e o aumento no peso de matéria seca da semente é mínimo. A segunda, denominada fase linear de enchimento, é o periodo de rápido incremento do peso da matéria seca devido a corversão de substância solúveis (açucares para amido, no endosperma). Durante este período mais de $90 \%$ da matéria seca do gråo já se encontra acumulada (JOHNSON \& TANNER, 1972). Durante a terceira fase, a taxa de acumulaçăo do peso da matéria seca declina, culminando com a maturidade fisiológica.

O crescimento do milho para produção de grăos é funçăo da taxa e duraçăo do período de enchimento do grăo (JOHNSON \& TANNER, 1972 e TOLLENAAR, 1977). O periodo de enchimento do grão, no milho, inicia-se na antese e continua até a formação da camada negra ou maturidade fisiológica (DAYNARD \& DUNCAN, 1969).

DAYNARD \& KANNENBERG (1976) estudaram a relaçẵo existente entre a produçăo de grăos do milho e duas medidas do comprimento do 
periodo de enchimento de grăos, ou seja, duraçăo atual do período de enchimento de grăo (número de dias de $50 \%$ do florescimento até a maturidade fisiológica) e duraçăo do período efetivo de enchimento (peso final do grão dividido pela taxa média de acumulaçzo do peso seco do grăo, na metade do período de enchimento de grăo). Pelos resultados obtidos, observaram que, geralmente, entre os hibridos estudados um prolongado periodo de enchimento de grão poderia resultar no aumento da produção.

Segundo JOHNSON \& TANNER (1972), a duraçăo do periodo de enchimento de grăo pode ser calculado a partir da produçăo final acrescido de duas ou três datas de amostragem após o forescimento.

No entanto, SAYRE (1948); HANWAY (1962) e DUNCAN \& HATFIELD (1964), relataram que considerável acumulo de peso da matéria seca do grăo é evidenciado, aproximadamente, entre 7 e 14 dias após $50 \%$ do florescimento e, o peso seco do grão de milho, obedece essencialmente uma taxa linear de acúmulo ao longo do tempo. Da mesma forma, JOHNSON \& TANNER (1972) concluiram que, no minimo, $90 \%$ do peso do grăo acumulado linearmente foi iniciado duas semanas e meia após a emergência dos estiloestigmas.

Um método simples da medição de duração do período de enchimento de grão pode envolver 0 uso de técnicas baseadas no desenvolvimento da camada negra. DAYNARD \& DUNCAN (1969) verificaram que o periodo de duraçăo de enchimento de grăos pode ser determinado pelo 
intervalo de tempo compreendido entre a emergencia dos estilo-estigmas até a formação da camada negra.

Dificuldades na identificação da data de maturidade do grão tem sido superado pelo reconhecimento da formação da camada negra na região placentária de sementes de milho, representando uma correta e simples indicação do máximo peso da matéria seca da semente (DAYNARD \& DUNCAN, 1969). Assim, em estudo relativo a quatro híbridos até o alcance da maturidade, observou-se que o aparecimento da camada negra ocorreu em três dias ou menos, em relação ao momento exato da deteç̧ão do máximo peso da matéria seca da semente.

Da mesma forma, RENCH \& SHAW (1971), visando determinar a afinidade entre o desenvolvimento da camada negra na semente, a acumulação de matéria seca e o grau de umidade, concluíram que a máxima acumulação da matéria seca da semente coincidiu com a ocorrência visual de formação da camada negra e, portanto, parece ser um método mais fácil de determinaçåo da maturidade fisiológica, em comparaçăo ao método de determinação de umidade. Observaram também que o teor de água das sementes, declinou significativamente durante o desenvolvimento da camada negra. Ainda, para os mesmos autores, a camada negra, em sementes maduras apresentaram graus de umidade que diferiram estatisticamente entre cultivares e dentro de cultivares semeados em datas diferentes.

Face ao exposto, mostra-se importante conhecer nåo somente o tempo necessário para cada hibrido de milho alcançar a maturidade fisiológica, 
mas também a relaçåo relativa da perda de umidade seguido da completa acumulação da matéria seca.

A medição do pico de acúmulo do peso da matéria seca tem sido extensamente usada como um método para se determinar a data da maturidade fisiológica, correspondente ao estádio 10, definido por Hanway² e, citado por FANCELLI (1986).

SHAW \& THOM (1951) determinaram a data da maturidade fisiológica, através da medição de acumulação de matéria seca no grăo. Em outro estudo, HANWAY \& RUSSELL (1969) registraram que a taxa de acumulação de matéria seca no grăo foi relativamente constante entre híbridos avaliados.

JOHNSON \& TANNER (1972) verificaram que a produçăo de grăo no milho é funçåo da taxa e duração de acumulaçăo de matéria seca no grăo.

Ainda, diferenças substanciais na duraçăo do periodo de enchimento de gråo ocorrem em diferentes híbridos de milho, com e entre maturidade relativa (DAYNARD, et al. 1971; DAYNARD 1972). A duraçăo do período de enchimento de grão, pode ser resultado do florescimento antecipado, da formação retardada da camada negra, ou da combinaçăo dos dois fatores.

Assim, visando estudar a maturidade do grâo de milho, foram avaliados três diferentes hibridos por SHAW \& THOM (1951), sendo que para os

2. BANWAY, J.J. Growth stages of corn (Zea mays L.) Agronomy Journal, Madison, 55: 487-492, 1963. 
quatro anos de experimento, a média do periodo de tempo do surgimento dos estilo-estigmas até a maturidade, para os três cultivares, foram correspondentes a 50,51 e 52 dias. Os autores verificaram, também, que foi relativamente constante o intervalo de tempo de, aproximadamente, 51 dias para completar exte período.

No estudo de duas linhas congênitas de milho e seus hibridos $F_{1}$, HALLAUER \& RUSSELL (1962) verificaram que os seus respectivos períodos de enchimento de grão foram relativamente constante, em tomo de 60 dias. A umidade do gråo na maturidade fisiológica do material estudado variou de $28,8 \%$ a $39,8 \%$, enfatizando que o teor de água do grăo, isoladamente, năo poderia ser considerado como exata indicação da maturidade.

Em contrapartida, HILLSON \& PENNY (1965) identificaram diferenças de oito dias ou mais entre os hibridos de milho, com relaçăo à duração do periodo de enchimento de grão.

Em estudo realizado com milho, destinando-se obter informaçбes a respeito de maturidade fisiológica e sua relaçăo de secagem, GUNN \& CHRISTENSEN (1965) constataram que, hibridos precoces alcançaram a maturidade fisiológica em menor número de dias, em comparação aos hibridos tardios, apresentando sementes maduras de mais baixo peso. Os híbridos tardios seriam caracterizados por apresentarem um periodo mais longo de enchimento de grăos. 
HANWAY \& RUSSELL (1969) estabeleceram correlação estreita entre a produção e duração do periodo de enchimento de grăo, em favor de alguns hibridos; quando comparado por um ano a uma populaçăo estabilizada de plantas. Foi constatada, também, diferença significativa ( 8 dias ou mais) entre os híbridos avaliados, quanto ao comprimento do periodo de enchimento de gråos.

CARTER \& PONELEIT (1973) evidenciaram grande diferença entre linhagens congénitas de milho, durante o desenvolvimento inicial e no comprimento do período de enchimento do grão. A divergência entre esses resultados é atribuida pela diferença na definiçăo de maturidade.

Em trabahos mais antigos, a maturidade foi muitas vezes determinada em função do teor de água da espiga, enquanto que em trabalhos mais recentes a maturidade fisiológica é definida como o estádio de máximo peso seco do grão.

Um estudo realizado em indiana, EUA, mostrou que a duração do periodo da emergéncia das plantas até a maturidade fisiológica do grâo de milho, teria aumentado nos últimos 30 anos, no periodo correspondido entre 0 ano de 1961 ate 1980. Entretanto, segundo McGARRAHAN \& DALE (1984) O comprimento do periodo da emergência dos estilo-estigmas até a maturidade fisiológica, teve um aumento de menos de 50 dias antes de 1961 até próximo de 60 dias em 1980 ou menos de 550 MGDD (crescimento modificado pelos graus-dia), antes de 1961 até próximo de 700 MGDD em 1980, referindose a quantidade térmica. Durante esse tempo, o melhoramento genético de milho 
para resistência a doenças e elevada produção, inconscientemente, pode ter prolongado o perlodo de enchimento de grão.

DAYNARD (1972), estudou no milho, a relação entre umidade de gräo e o desenvolvimento da camada negra, bem como o efeito do ambiente sobre o comprimento do intervalo da emergência ao florescimento até a formação da camada negra, calculado em graus-dia. Verificou que o atraso na semeadura resultou na redução do número de dias da emergência até o florescimento e o aumento no número de dias do florescimento até a maturidade. O atraso da semeadura resultou no aumento do número de unidades de calor acumulado do plantio até o florescimento e uma reduçăo nas unidades de calor acumulada do fiorescimento até a maturidade fisiológica.

A avaliação da duração do ciclo da cultura do milho com base nos dias do calendário, apesar de ser bastante utilizada, tem-se mostrado como um método bastante impreciso.

De acordo com Hanna 3 , citado por GILMORE \& ROGERS (1958), apesar do conjunto de fatores do meio ambiente influir no desenvolvimento da cultura do milho, a temperatura do ar é a variável climática mais importante, estando acentuadamente correlacionada com 0 desenvolvimento da planta.

A temperatura do ar vem sendo bastante utilizada sob a forma de indices bioclimáticos na caracterização da ocorrência de estádios fenológicos 
das culturas (GILMORE \& ROGERS, 1958). Dentre esses indices, destaca-se o conceito de graus-dia que consiste na somatória da temperatura diária do ar acima de um valor-base, abaixo do qual cessa o desenvolvimento desta cultura. A duração dos estádios fenológicos, avaliada pelo método de graus-dia, tem-se mostrado superior à estimativa baseada nos dias do calendário (COSTA et al., 1986). Isto se explica pelo fato de o crescimento e o desenvolvimento da cultura estarem mais relacionados com a temperatura do at do que com os dias do calendário.

GUNN \& CHRISTENSEN (1965) verificaram a correta eficiência na determinaçăo em graus-dia do perlodo da semeadura até a emergência dos estilo-estigmas em vánias localidades e anos. A correlaçăo mostrou-se positiva entre a eficiência em graus-dia para a emergência dos estiloestigmas e a porcentagem de umidade em todos os estádios de desenvolvimento.

DUNCAN et al. (1965) e RAGLAND et al. (1965), verificaram - efeito da temperatura no desemvolvimento de linhagens e hibridos de milho, sendo o comprimento do perlodo de enchimento de grâos, bem como o número de dias, calculado em termos de unidade de calor e expresso em graus-dia.

DAYNARD et al. (1971); DAYNARD \& DUNCAN (1969); HANWAY \& RUSSELL (1969); PEASLEE et al. (1971) e CROSBIE \& MOCK (1981) mostraram que o periodo de enchimento de grão no milho esta altamente correlacionado com a produção dessa cultura. Deste modo, o aumento na produçấo de milho mostraria, em parte, uma tendéncia da longevidade do 
período de enchimento, talvez compensado pelo aumento na densidade de plantio e acentuado aumento na taxa de $P$ e $K$. 


\section{MATERIAL E MÉTODOS}

\subsection{Localização}

- experimento foi conduzido em área pertencente ao Departamento de Agricultura da Escola Superior de Agricultura "Luiz de Queiroz", da Universidade de São Paulo (ESALQNSP), no municipio de Piracicaba, SP.

\subsection{Dados Meteorológicos}

Os dados meteorológicos, foram fornecidos pelo Posto Agrometeorologico do Departamento de Fisica e Meteorologia da ESALQIUSP, sendo referentes à precipitação pluvial e às temperaturas máximas e minimas, ocorridas durante o período experimental, conforme apresentado no apêndice I. 


\subsection{Cultivares utilizados}

Os cultivares de mitho utilizados foram XL 380, BR 201 e

Pioneer 3072, de diferentes ciclos, ou seja, normal, precoce e superprecoce, respectivamente.

As caracteristicas de cada cultivar, encontram-se discriminadas na Tabela 1 :

Tabela 1. Características dos cultivares de milho avaliados(*)

\begin{tabular}{llllll}
\hline $\begin{array}{l}\text { Nome } \\
\text { Comercial }\end{array}$ & Tipo de hibrido & $\begin{array}{l}\text { Ciclo e unida- } \\
\text { des de calor }\end{array}$ & $\begin{array}{l}\text { Floresci- } \\
\text { mento }\end{array}$ & $\begin{array}{l}\text { Altura das plan } \\
\text { tas }\end{array}$ & $\begin{array}{l}\text { População } \\
\text { (PUha) }\end{array}$ \\
\hline XL 380 & $\begin{array}{l}\text { Hibrido tripto } \\
\text { Normal }\end{array}$ & $\begin{array}{l}\text { Normall915 } \\
\text { U.C. }\end{array}$ & $60-65$ dias & $\begin{array}{l}\text { Media } \\
(2,05-2,30 \mathrm{~m})\end{array}$ & $\begin{array}{l}50.000- \\
55.000\end{array}$ \\
BR 201 & Hibrido duplo & $\begin{array}{l}\text { Precoce/855 } \\
\text { U.C. }\end{array}$ & 62 dias & $2,33 \mathrm{~m}$ & $\begin{array}{l}40.000- \\
60.000\end{array}$ \\
P3072 & $\begin{array}{l}\text { Hibrido sim- Superprecoce } \\
\text { ples modifica- } \\
\text { do }\end{array}$ & 507 U.C. & & $2,00 \mathrm{~m}$ & 55.000 \\
& & & & 70.000 \\
\hline
\end{tabular}

( $)$ Dados fornecidos pelas Empresas produtoras dos hibridos.

\subsection{Tratamentos}

Foram utilizados para os três cultivares, quatro niveis de $\mathrm{N}$, sendo $0,50,100$ e $150 \mathrm{~kg} / \mathrm{ha}$ (NO, N1, N2 e N3) na forma de uréia, totalizando doze tratamentos, conforme visualizados à seguir: 


\begin{tabular}{|c|c|c|c|c|}
\hline \multirow[b]{2}{*}{ Cultivares/ciclo } & \multicolumn{4}{|c|}{ Niveis de Nitrogênio } \\
\hline & 0 & 50 & 100 & 150 \\
\hline $\begin{array}{l}X \mathrm{X} 380 \\
\text { (Normal) }\end{array}$ & c1NO & c1N1 & $\mathrm{c} 1 \mathrm{~N} 2$ & $\operatorname{c1N3}$ \\
\hline $\begin{array}{l}\text { BR } 201 \\
\text { (Precoce) }\end{array}$ & $\mathrm{C} 2 \mathrm{NO}$ & c2N1 & $\mathrm{C} 2 \mathrm{~N} 2$ & $\mathrm{c} 2 \mathrm{~N} 3$ \\
\hline $\begin{array}{l}\text { P } 3072 \\
\text { (Superprecoce) }\end{array}$ & C3NO & C3N1 & C3N2 & c3N3 \\
\hline
\end{tabular}

\subsection{Procedimento experimental e colheita}

O experimento foi conduzido em esquema de parcelas subdivididas, obedecendo o delineamento de blocos ao acaso, com três repetiçסes, onde as parcelas foram constituidas pelos cultivares e as subparcelas pelos niveis de nitrogênio (cultivar $=\mathrm{c} 1, \mathrm{c} 2$ e c3; nivel $=\mathrm{NO}, \mathrm{N} 1, \mathrm{~N} 2$ e N3).

Cada parcela foi constituida de quatro linhas de $6 \mathrm{~m}$ de comprimento, espaçadas entre si de $0,90 \mathrm{~m}$, apresentando 5 plantas por metro linear de sulco, obtidas após desbaste, sendo consideradas úteis apenas as duas linhas centrais.

Os resultados da análise quimica do solo, classificado como Terra Roxa estruturada eutrófica relativo ao local de instalação do experimento são apresentados na Tabela 2. 
Tabela 2. Resultados da análise química do solo

\begin{tabular}{|c|c|c|c|c|c|c|c|c|c|}
\hline \multirow[t]{2}{*}{$\begin{array}{l}\mathrm{PH} \\
\mathrm{CaCl}_{2}\end{array}$} & \multirow[t]{2}{*}{$\begin{array}{l}\text { Matéria } \\
\text { Organica \% }\end{array}$} & \multirow[t]{2}{*}{$\begin{array}{l}\text { P resina } \\
\text { ppm }\end{array}$} & $\bar{k}$ & $\mathrm{Ca}$ & $\mathrm{Mg}$ & $\mathrm{H}+\mathrm{Al}$ & $\bar{s}$ & $T$ & \multirow[t]{2}{*}{$\begin{array}{l}V \\
\%\end{array}$} \\
\hline & & & \multicolumn{6}{|c|}{$\mathrm{meq} / 100 \mathrm{~cm}^{3}$} & \\
\hline$\overline{5,4}$ & 2,8 & 46 & 0,63 & 8,5 & 2,6 & 3,8 & 11,7 & 15,5 & 75 \\
\hline
\end{tabular}

As quantidade de uréia ministradas bem como o esquema de fracionamento utilizado, encontram-se descritos na Tabela 3.

Tabela 3. Esquema de adubação nitrogenada empregada no experimento de milho safrinha. Piracicaba, SP.

\begin{tabular}{ccccc}
\hline $\begin{array}{c}\text { Nivel de } \\
\text { Nitrogénio }\end{array}$ & Kg/ha de $N$ & Semeadura & $\begin{array}{c}\text { 1a Cobertura } \\
\text { (35 DAE) }\end{array}$ & $\begin{array}{c}\text { 2a Cobertura } \\
\text { (49 DAE) }\end{array}$ \\
\hline No & 0 & 0 & 0 & 0 \\
N1 & 50 & 20 & 15 & 15 \\
N2 & 100 & 20 & 40 & 40 \\
N3 & 150 & 20 & 65 & 65 \\
\hline
\end{tabular}

DAE: Dias Após Emergência

Em todos os tratamentos foram aplicados, $100 \mathrm{~kg} / \mathrm{ha}$ de $\mathrm{P}_{2} \mathrm{O}_{5}$ e $75 \mathrm{~kg} / \mathrm{ha}$ de $\mathrm{K}_{2} \mathrm{O}$, sob as formas de superfosfato simples e cloreto de potássio, respectivamente. Cumpre ressaltar que o adubo potássico foi parcelado (50 $\mathrm{kg} / \mathrm{ha}$ na semeadura e $25 \mathrm{~kg} / \mathrm{ha}$ em cobertura, 35 dias após a emergência das plantas), ao passo que o fósforo foi totalmente fornecido por ocasiåo da 
semeadura. Salienta-se que as adubaçōes de fundaçắo e cobertura foram realizadas manualmente.

A semeadura foi efetuada no dia 13 de janeiro de 1993, sendo o desbaste efetuado 21 dias após a emergência, deixando-se o número desejado de plantas em cada unidade experimental, ou seja, 5 plantas $/ m$. O controle de plantas daninhas foi efetuado com o herbicida 2,4-D, na dosagem de $0,8 \mathrm{l} / \mathrm{ha}$, mediante pulverizador de barra acoplado em trator, 28 dias após a emergência das plantas.

Foram realizadas 9 (nove) amostragens, efetuadas durante 0 periodo de enchimento de grăos, através das quais foi determinada a taxa de acúmulo de matéria seca. Para tanto foram coletadas as espigas de duas plantas por subparcelas, colhidas das duas fileiras centrais (uma por fileira), em intervalos de 7 dias, durante oito semanas consecutivas. Foram colhidas 18 plantas da área útil e as demais foram utilizadas na determinaçăo da produçào final.

A colheita foi realizada no dia 16 de junho de 1993, para determinaçăo da produçăo final, coletando todas as espigas presentes na area útil para produção de grãos das parcelas. 


\subsection{Caracteres Avaliados}

Para fins de avaliação, os caracteres estudados foram divididos em dois grupos:

\subsubsection{Caracteres agronômicos}

Foram considerados como caracteres agronômicos aqueles avaliados desde a emergência até a colheita, ou seja;

\section{a) Altura da planta (cm)}

O referido componente consistiu na média anitmética simples das atturas de trés plantas avaliadas em cada, subparcela; considerando-se a distancia da superficie do solo à curvatura da folha bandeira, quando as plantas já haviam emitido o pendåo (MAGALHÃES et al., 1993).

\section{b) Índice de área follar}

Inicialmente a área foliar total da planta fol determinada através do cálculo da superficie da área foliar mediante 0 uso da seguinte expressåo matemática: comprimento foliar $x$ largura máxima $\times 0,75$, conforme proposto por FRANCIS et al. (1969). O cálculo do IAF foi obtido pelo valor do 
quociente da área foliar total da planta pela área do terreno disponivei para a planta, ou seja:

$$
\text { IAF =AFIS, }\left(\mathrm{cm}^{2} \text { área foliaricm² área terreno }\right)
$$

\section{c) Graus-dla ou somatória calórica}

Para obtenção das unidades de calor ou graus-dia, foi utilizada a seguinte fórmula:

$$
\begin{aligned}
& \text { GD }=\sum\{(T \min +T \max ) / 2\}-T \text { base onde, } \\
& T \text { min } \geq 10^{\circ} \mathrm{C} \\
& T \text { max } \leq 30^{\circ} \mathrm{C} \\
& \text { Tbasal }=10
\end{aligned}
$$

Os periodos avaliados foram: da emergência ao inicio do periodo de enchimento de grãos (Fase 1) e (Fase 2) periodo de enchimento de grãos (50\% de florescimento até maturidade fisiológica).

\subsubsection{Componentes da produçäo}

Dentro dessas variáveis foram englobados todos os caracteres avaliados após a colheita. 


\section{a) Número de espigas por planta}

No momento da calheita determinou-se o número de plantas estéreis e aquelas apresentando uma ou mais espigas. Assim, obteve-se o número de espigas por planta, dividindo-se o número de espigas colhidas pelo total de plantas presentes na área útil da parcela.

\section{b) Comprimento da espiga (cm)}

Todas as espigas colhidas foram conduzidas ao laboratório,onde foi determinado o comprimento das mesmas mediante amostra composta por dez espigas coletadas ao acaso, por subparcela.

\section{c) Peso de espiga}

Após a colheita manual, todas as espigas foram pesadas com palha, sendo os valores transformados em $\mathrm{kg} / \mathrm{ha}$. 


\section{d) Produçäo de gräos}

Foi obtida de plantas colhidas nas duas fileiras centrais de cada subparcela. Ainda, após a debulha manual de todas as espigas, uma amostra de grăos foi separada para a determinaçăo do grau de umidade no aparelho de marca STEINLITE, possibilitando a correção do peso de grãos para $14 \%$ de água. Assim, após a determinaçăo do teor de água, foi efetuada a correçåo dos valores de produçăo, em $\mathrm{kg} / \mathrm{ha}$.

\section{e) Acúmulo de matéria seca dos grãos}

Quando $50 \%$ das plantas encontraram-se na fase de florescimento foram iniciadas as amostragens de plantas. Para tal determinaçăo, espigas de duas plantas por subparcela foram colhidas e cada grupo de espigas foi individualizada em suas partes (palha + sabugo + grăo) e encaminhadas ao laboratório. O material recebeu o tratamento necessário para análises dessa natureza, sendo colocado para secar em estufa a $70^{\circ} \mathrm{C}$ até obtenção do peso constante. Após o resfriamento do material, procedeu-se sua pesagem.

No total, foram coletadas nove amostras, a partir de 75 dias após a emergência (DAE), até todos os tratamentos atingirem $50 \%$ de formação da camada negra; o que foi evidenciado, aos 130, 123 e 111 DAE, para os cultivares $c 1=X L 380, c 2=B R 201$ e $c 3=P 3072$, respectivamente. 


\subsection{Análise estatistica}

Os dados observados foram submetidos à análise de variancia pelo teste $F$, sendo as diferenças de médias entre tratamentos comparadas pelo teste de Tukey, ao nivel de $5 \%$ de probabilidade. Ainda, salienta-se que os dados obtidos para nủmero de espigas por planta, foram transformados para arc sen $\sqrt{ } \times 100$

Para as características estudadas foi efetuada a análise estatística fundamentada no esquema de variancia apresentado a seguir:

\begin{tabular}{lc}
\hline Causas de variação & Grau de Liberdade \\
\hline Blocos & 2 \\
Cultivares & 2 \\
Residuo (A) & 4 \\
Parcelas & 8 \\
Doses N & \\
CXD & 3 \\
Residuo (B) & 6 \\
Total & 18 \\
\hline
\end{tabular}




\section{RESULTADOS}

\subsection{Avaliaçóes de campo}

\subsubsection{Altura de planta}

A análise de variância dos dados altura de planta (ALT), revelou valor de $F$ significativo $(P<0,01)$ para os cultivares e doses de nitrogénio; entretanto năo foi significativo para a interaçăo cultivar $x$ doses $(0,38 ; P>0,05)$, conforme observado na tabela 5 .

Pode-se observar na tabela 6 , que a maior attura foi verificada no cultivar de ciclo normal (média de $197 \mathrm{~cm}$ ), enquanto que a menor altura foi observado no cultivar precoce (média de $178 \mathrm{~cm}$ ).

Com relaçåo as doses de nitrogênio, constatou-se que o valor de $F$ foi significativo, pelo teste de Tukey $(P<0,05)$. Pelas médias, verificou-se 
que a menor altura ficou com a dose $0(173 \mathrm{~cm})$, não diferindo das doses $50 \mathrm{e}$ $100 \mathrm{~kg} / \mathrm{ha}$ de $\mathrm{N}$ com 185 e $190 \mathrm{~cm}$, respectivamente. A maior altura foi obtida para a dose $150 \mathrm{~kg} / \mathrm{ha}$ de $\mathrm{N}_{1}(197 \mathrm{~cm})$, conforme visualizado na tabela 7 .

O comportamento da altura de planta em função do acréscimo de nitrogênio ao solo, pode ser evidenciado na figura 1. Verifica-se que a altura aumenta com as doses crescentes de nitrogénio e que o cultivar de ciclo normal comportou-se melhor em todas as doses de $\mathrm{N}$ aplicadas ao solo.

\subsubsection{Indice de area foliar}

A análise dos dados referente ao indice de área foliar (IAF), apresentou valor de $F$ significativo $(P<0,01)$, para os fatores cultivares e doses de nitrogênio, contudo não foi constatado significância na interação cultivar $x$ doses, conforme observado na tabela 5 .

As médias dos cuttivares, através do teste de Tukey $(P<$ $0,05)$, mostraram diferenças significativas entre si. Verificou-se na tabela 6 que 0 IAF do cultivar de ciclo normal, apresentou o maior valor, em relaçăo ao menor valor apresentado pelo cultivar superprecoce. Porém náo se constatou efeito significativo para o cultivar precoce.

Pela análise da tabela 7 , observou-se que o valor do $F$, foi significativo, indicando que as doses de nitrogênio, influiram no IAF das plantas. Pelas médias, verificou-se que a dose de $150 \mathrm{~kg} / \mathrm{ha}$ de $\mathrm{N}$, apresentou valor 
médio do IAF $(3,23)$ superior a dose zero $(2,31)$, entretanto nāo houve diferença significativa entre 50 e $100 \mathrm{~kg} / \mathrm{ha}$ de $\mathrm{N}$.

O comportamento do IAF em função do acréscimo de $\mathrm{N}$ ao solo, pode ser observado na figura 2. Evidenciou-se uma tendência do IAF aumentar com o acréscimo do $\mathrm{N}$ ao solo, e que o cultivar de cício normal, comportou-se melhor em todas as doses de $\mathrm{N}$, adicionado ao solo.

\subsubsection{Graus-dia}

O número de graus-dia durante o periodo entre a emergéncia e o florescimento variou com a época de semeadura considerada "safrinha"e entre os cultivares, tendo sido obtidos 892,838 e 812 , respectivamente para os cultivares XL 380, BR 201 e P 3072. (Tabela 4).

Tabela 4. Graus-dia, para os três cultivares de milho de diferentes ciclos. Piracicaba, SP. 1993.

\begin{tabular}{lcc}
\hline Culitvares & Emergência ao florescimento & $\begin{array}{l}\text { Florescimento à maturidade } \\
\text { fisiologica }\end{array}$ \\
\hline XL 380 & 891,8 & 775,1 \\
BR 201 & 838,4 & 771,3 \\
P 3072 & 812,0 & 752,6
\end{tabular}




\subsection{Componentes da produçăo}

\subsubsection{Número de espigas por planta}

A análise de variância, para o componente número de espigas por planta (NES), apresentou valor do $F(8,42)$ significativo $(P<0,01)$ apenas para o fator doses de nitrogênio. Com relação ao fator cultivares, verificou-se que não foi significativo $(P>0,05)$, indicando a sua não influência neste parâmetro. Os dados da interação cultivar $x$ doses, pelo teste $F(0,37)$ revelou não apresentar diferenças significativas $(P>0,05)$, conforme observado na tabela 5 .

Analisando as médias destes materiais (tabela 6), observou-se que o cultivar precoce, apresentou de modo geral, valor superior, quando comparado aos demais cultivares.

Pode-se constatar na tabela 7 , que 0 valor de $F$ foi significativo, com relaçāo as doses de nitrogênio. Pelas médias, o maior número de espigas encontrado, foi relacionado a dose de $150 \mathrm{~kg} / \mathrm{ha}$ de $\mathrm{N}$ (NES = 1,8889 ), não diferindo das doses 50 e $100 \mathrm{~kg} / \mathrm{ha}$ de $\mathrm{N}$, avaliado pelo teste de Tukey $(P<0,05)$.

$O$ efeito de cuttivares e doses de nitrogénio sobre O NES, pode ser evidenciado na figura 3. O NES aumentou com os acréscimos nas 
doses de nitrogênio e o cultivar precoce, comportou-se melhor em todas as doses de $\mathrm{N}$ adicionado ao solo.

\subsubsection{Comprimento da espiga}

A análise de variáncia, referente ao comprimento da espiga (CES), revelou valor de $F$ significativo $(P<0,01)$ para os cultivares e doses de nitrogênio. Com relação a interação cultivar $x$ doses, verificou-se que não foram significativos, conforme observado na tabela 5 .

Entre os hibridos (tabela 6), observou-se que houve diferença significativa, através do teste de Tukey $(P<0,05)$, com o valor médio alcançado pelos cultivares normal $(16,65 \mathrm{~cm})$ e precoce $(16,58 \mathrm{~cm})$ superior ao do cultivar superprecoce $(15,28 \mathrm{~cm})$.

Pela análise da tabela 7 , constatou-se que as doses 100 e 150 $\mathrm{kg} / \mathrm{ha}$ de $\mathrm{N}$, apresentaram valor médio superiores $(16,68 \mathrm{~cm}$ e $17,04 \mathrm{~cm})$ as demais, pelo teste de Tukey $(P<0,05)$.

Analisando o comportamento da variável (CES), verifica-se que existe uma tendência da mesma, aumentar com o acréscimo de nitrogênio ao solo, conforme representação gráfica da curva apresentando na Figura 4.0 cultivar de ciclo normal, comportou-se melhor em todas as doses de $\mathrm{N}$ aplicado ao solo. 


\subsubsection{Peso de espiga}

Os dados correspondentes ao peso de espiga (PES), submetidos à análise de variância, mostraram que o valor de $F(137,38)$ foi estatisticamente significativo $(P<0,01)$ para todos os cultivares, o mesmo nåo ocorrendo para as doses de nitrogênio que apresentaram valor $F$ de 2,92 ( $P$ ) $0,05)$. Os dados da interaçăo cultivar $x$ doses, pelo Teste $F$, revelaram não existir diferenças significativas, conforme observado na tabela 5 .

As medias dos cultivares (tabela 6), através do teste de Tukey, mostraram diferenças significativas entre si para $P<0,05$. Assim o PES foi maior para o cultivar precoce obtendo-se produção de $11.551 \mathrm{~kg} / \mathrm{ha}$, enquanto que 0 menor foi verificado para a produção do cultivar superprecoce, ou seja, 4.292 kgha.

Analisando as médias das diferentes doses de nitrogênio, verificou-se que a dose $150 \mathrm{~kg} / \mathrm{ha}$ de $\mathrm{N}$ apresentou de modo geral, valor superior, quando comparado com as demais doses, conforme evidenciando na tabela 7.

A representação gráfica da equação de regressão que expressa os efeitos de cultivares e de doses de nitrogénio sobre o PES, pode ser observado na figura 5. O cultivar precoce, comportou-se melhor em todas as doses de $N$, existindo tendência do PES aumentar com doses crescentes de nitrogênio adicionado ao solo. 


\subsubsection{Produção de grãos}

Estudando o comportamento da variável produção de grão (PG), verificou-se pela análise de variância (tabela 5), que o valor de $F(75,78)$ foi estatisticamente significativo $(P<0,01)$ para os cultivares, o mesmo nåo ocorrendo para as doses de nitrogênio apresentando valor de $F$ de 2,89 ( $P$ > 0,05). Para a produçăo foi verificado também que nåo existiu interaçăo entre cultivar $x$ doses $(F=0,87 ; P>0,05)$.

Através do teste de Tukey, constatou-se efeito significativo entre os cultivares. Pode-se verificar na tabela 6 , que a produçăo de grăos foi maior para o cultivar precoce, $(6.275 \mathrm{~kg} / \mathrm{ha})$, enquanto que o menor rendimento foi verificado no cuttivar superprecoce, ( $2.872 \mathrm{~kg} / \mathrm{ha})$

Pela análise da tabela 7 , verificou-se que o valor de $F(2,89)$ não foi significațivo, com relação as doses de nitrogênio. Analisando as médias destes materiais, observou-se que a dose $150 \mathrm{~kg} / \mathrm{ha}$ de $\mathrm{N}$ apresentou, de modo geral, valor superior, quando comparado com as demais.

o comportamento da PG, em funçăo do acréscimo de nitrogênio ao solo, pode ser observado na Figura 6. Constatou-se a existência da nitida tendência de aumento da produção com doses crescentes de nitrogênio ao solo, e que o cultivar precoce, comportou-se melhor em todas as doses de $\mathrm{N}$ avaliadas. 


\subsubsection{Acúmulo de matéria seca dos gråos}

Os valores referentes ao peso de matéria seca dos grãos (média de seis plantas) encontram-se apresentados na tabela 8.

A análise de regressão mostrou que o acúmulo de matéria seca dos grãos é melhor representado por equações lineares ou quadrática. A representação gráfica das curvas e as equaçōes correspondentes para cada cultivar e niveis de nitrogênio, encontram-se nas figuras 7,8 e 9 .

Variaçåo nas doses de nitrogênio, resultou em diferentes niveis de acumulação de matéria seca do grão; observando-se que os maiores indices de acúmulos de matéria seca dos grãos, foram correlacionados as maiores doses de nitrogênio, para os três cultivares de diferentes ciclos.(Figuras 7,8 e 9). Para efeito de melhor visualização do acúmulo de matéria seca do grão foram utilizados gráficos de colunas, conforme verificado nos apêndices III, IV e V.

Verificou-se na Tabela 8 , que na dose $150 \mathrm{~kg} / \mathrm{ha}$ de $\mathrm{N}$, o ponto de máximo acúmulo de matéria seca do grão foi obtido 130 DAE $\left(683,22 \mathrm{~g} / \mathrm{m}^{2}\right)$ no cultivar de ciclo normal, $116 \mathrm{DAE}\left(758,72 \mathrm{~g} / \mathrm{m}^{2}\right)$ no cultivar precoce e 109

DAE $\left(387,5 \mathrm{~g} / \mathrm{m}^{2}\right)$ no cultivar superprecoce, correspondente ao ponto de maturidade fisiológica. 
A duraçăo do periodo de enchimento de grăo (PEG), foi calculado a partir do número de dias relacionado a ocorrência de $50 \%$ do florescimento das plantas presentes na área até a maturidade fisiológica (DAYNARD \& KANNENBERG, 1976). Entretanto nas condições do experimento, não se verificou diferenças significativas para formação da camada negra $(50 \%$ dos grãos) em função dos diferentes niveis de nitrogênio estudados.

Assim, o número de dias obtido entre o florescimento e 0 aparecimento da camada negra na maioria dos gråos das espigas foram 65,62 e 54 dias, respectivamente para os cultivares XL 380, BR 201 e $P 3072$. 


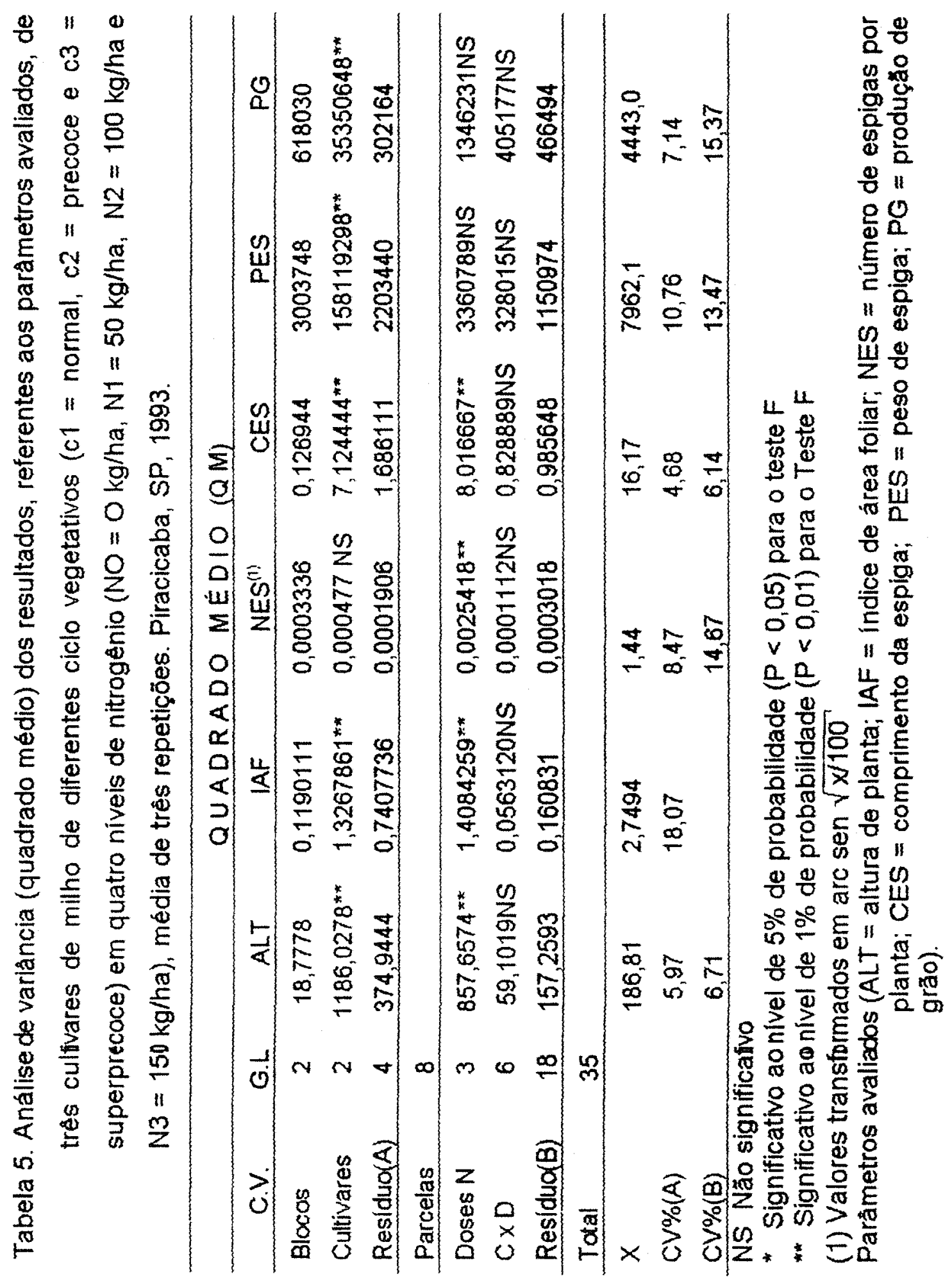




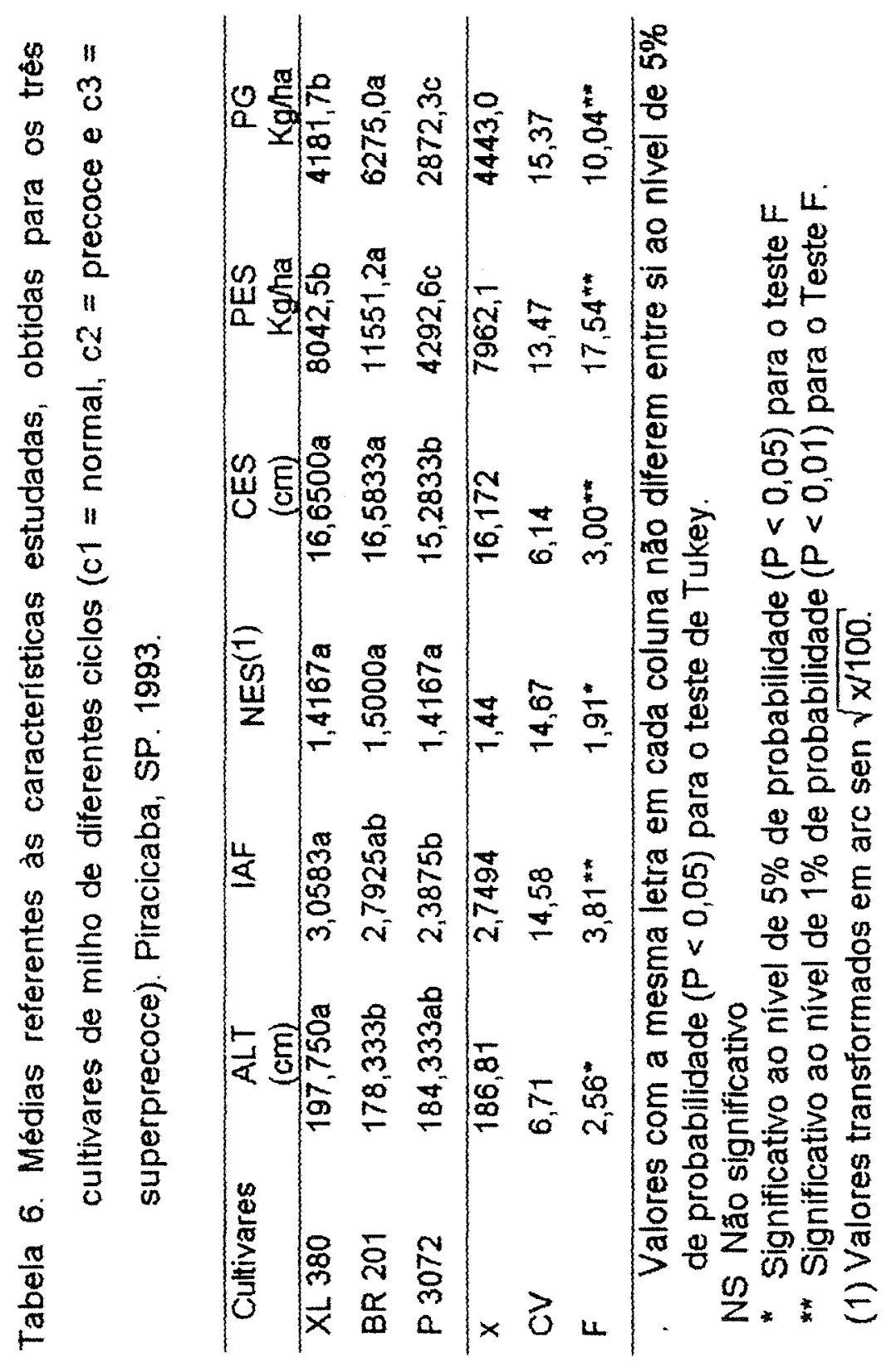




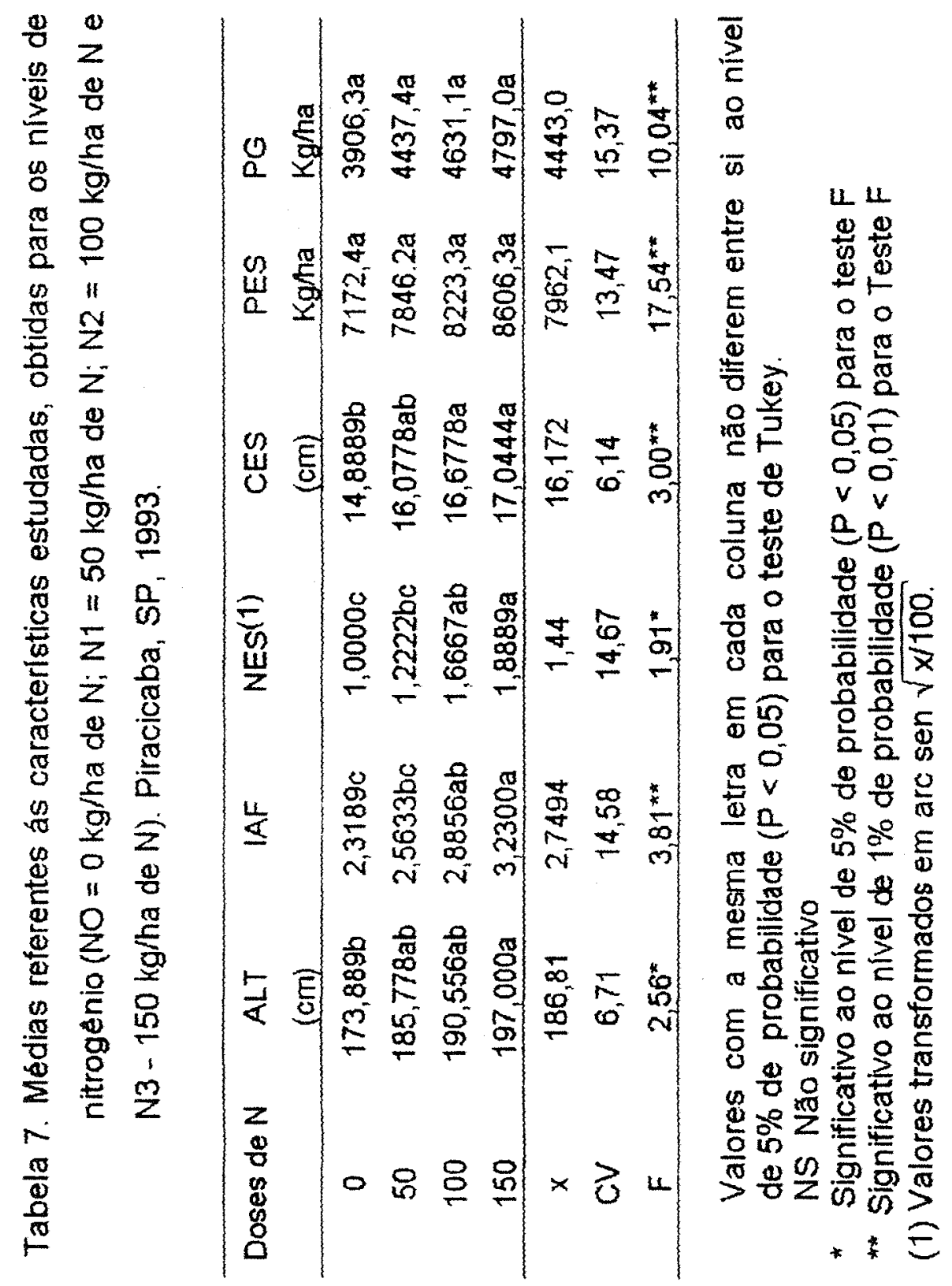




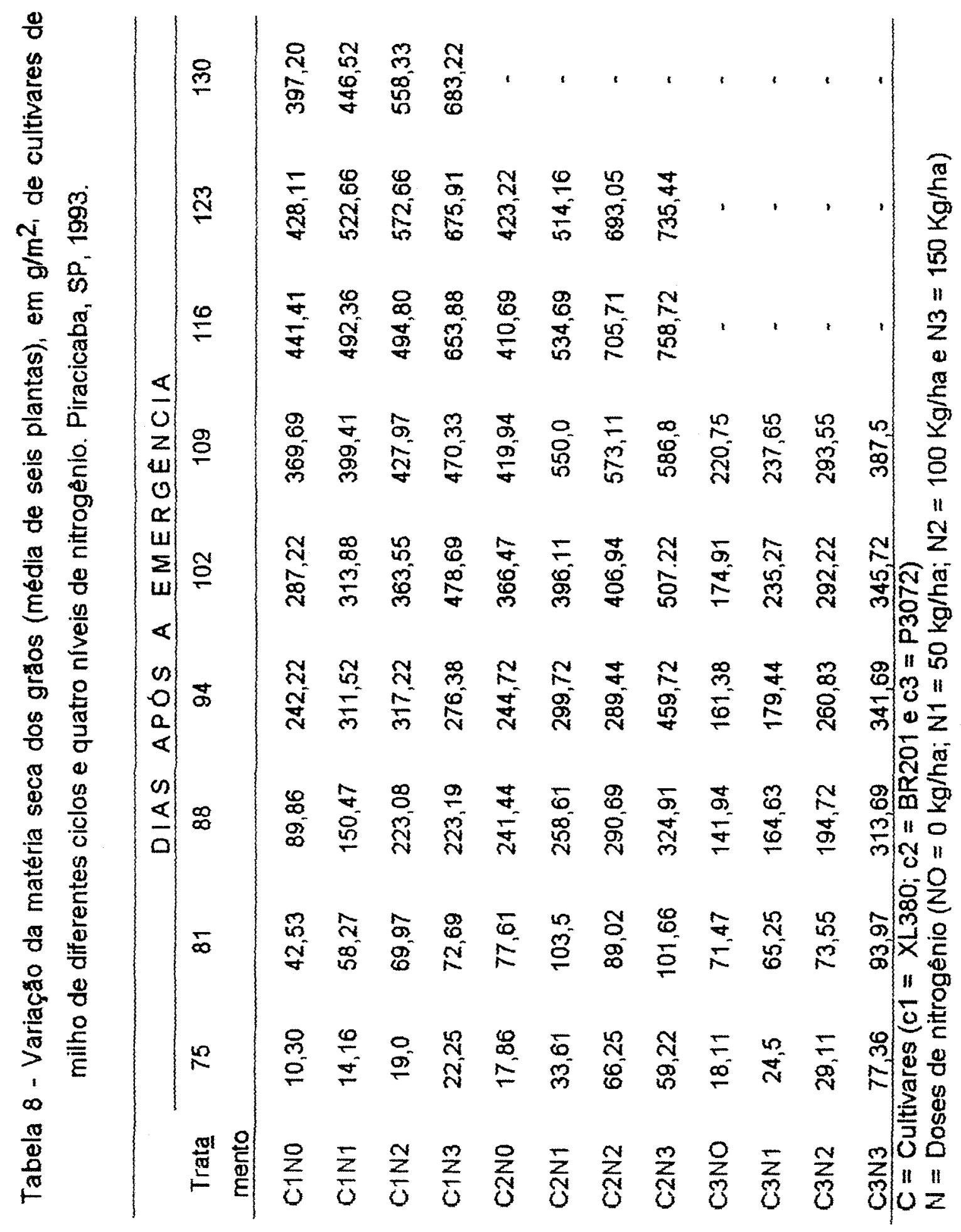






Figura 1. Representação gráfica da equação de regressão que expressa os efeitos de cultivares e doses de nitrogênio sobre a altura. 


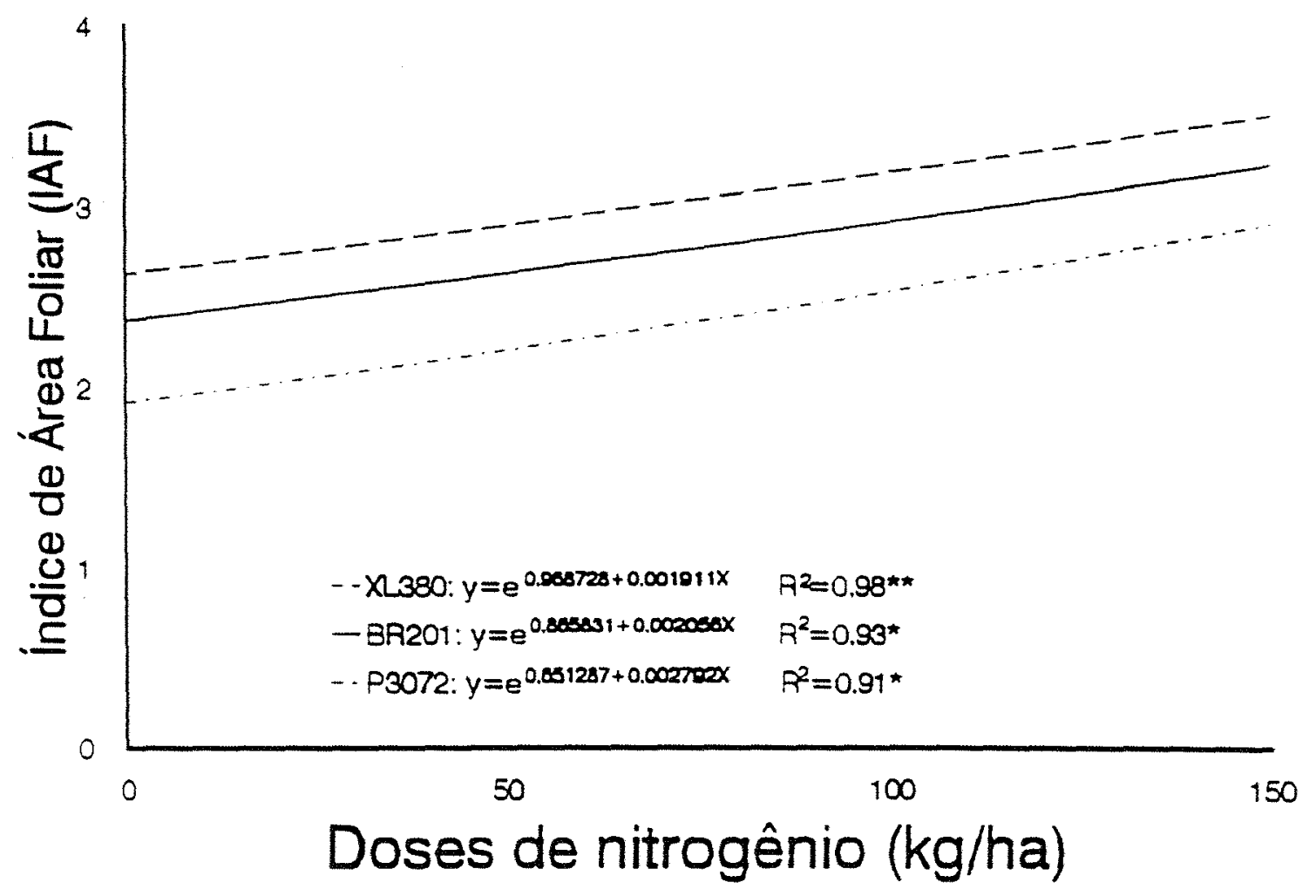

Figura 2. Representação gráfica da equação de regressão que expressa os efeitos de cultivares e doses de nitrogênio sobre indice de área foliar 




Figura 3. Representação gráfica da equação de regressão que expressa os efeitos de cultivares e doses de nitrogênio sobre o numero médio de espiga por planta 


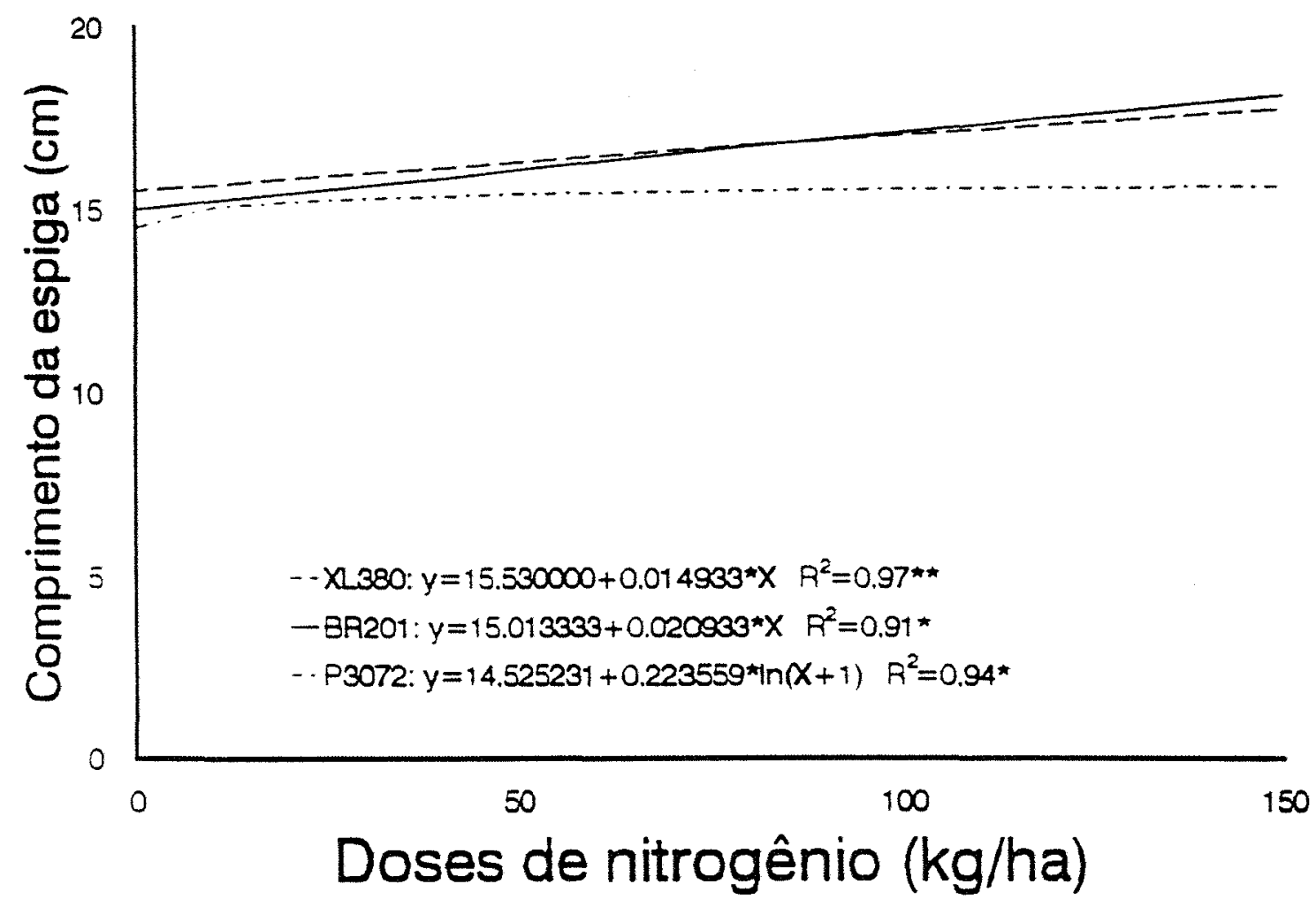

Figura 4. Representação gráfica da equação de regressão que expressa os efeitos de cultivares e doses de nitrogênio sobre o comprimento da espiga 


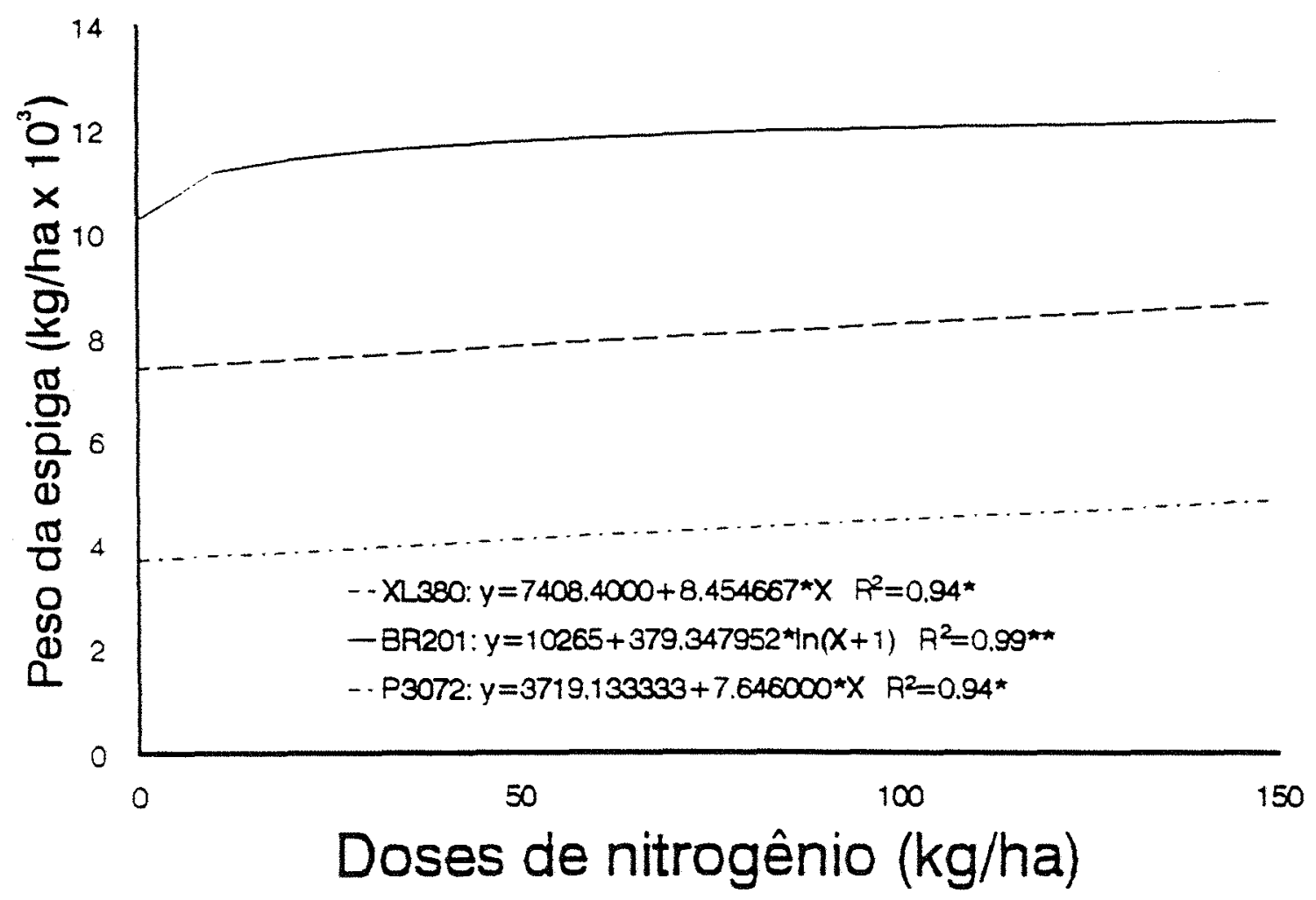

Figura 5. Representação gráfica da equação de regressão que expressa os efeitos de cultivares e doses de nitrogênio sobre o peso da espiga. 


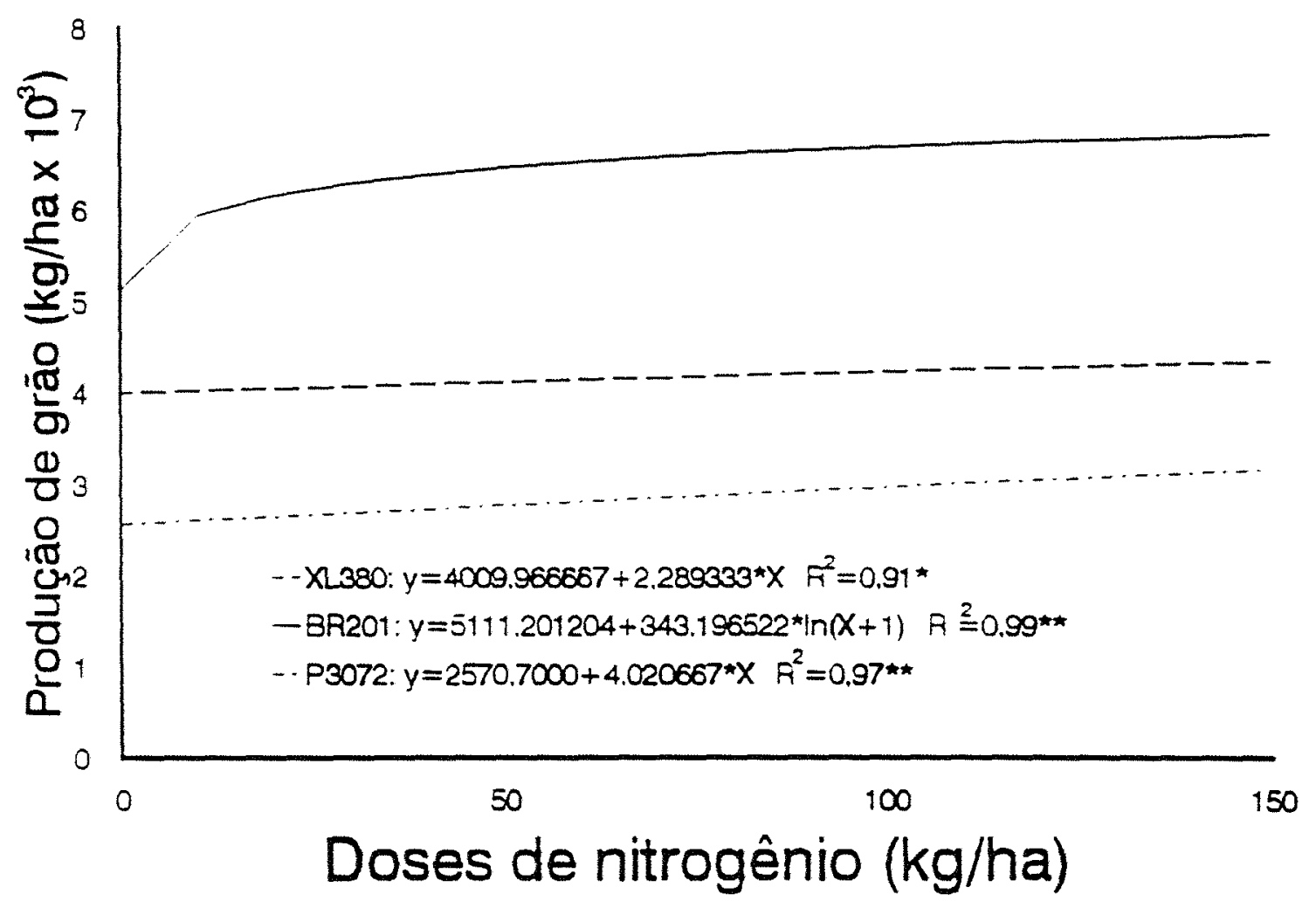

Figura 6. Representação gráfica da equação de regressão que expressa os efeitos de cultivares e doses de nitrogênio sobre a produção 
-NO: $y=-491.342588+7.113078 x R^{2}=0.72 * \star$

…N50: $y=-2750.782913+52.506436 x-0.216092 X^{2} R^{2}=0.87^{\star \star}$

$-N 100: y=-2318.956602+42.948674 X-0.160004 X^{2} R^{2}=0.93^{\star *}$

- N150: $y=-910.275897+12.828100 X R^{2}=0.90^{\star \star}$



Figura 7. Acumulo da materia seca do grão em cultivar de milho de ciclo normal $(c l=X L 380)$ e quatro niveis de nitrogênio. Piracicaba, SP. 1993. 


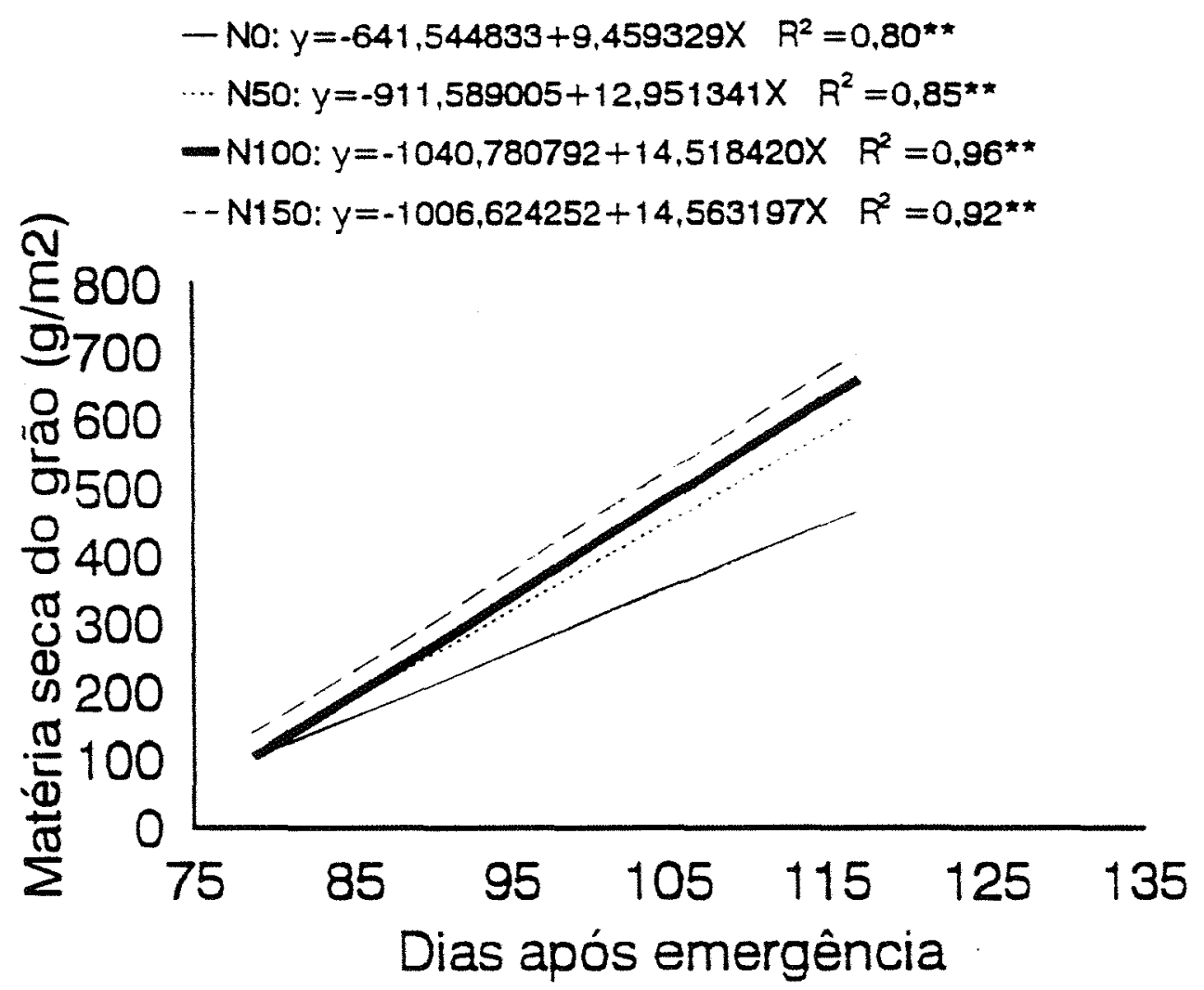

Figura 8. Acumulo da matéria seca do grão em cultivar de milho de ciclo precoce $(c 2=B R 201)$ e quatro niveis de nitrogênio. Piracicaba, SP. 1993. 


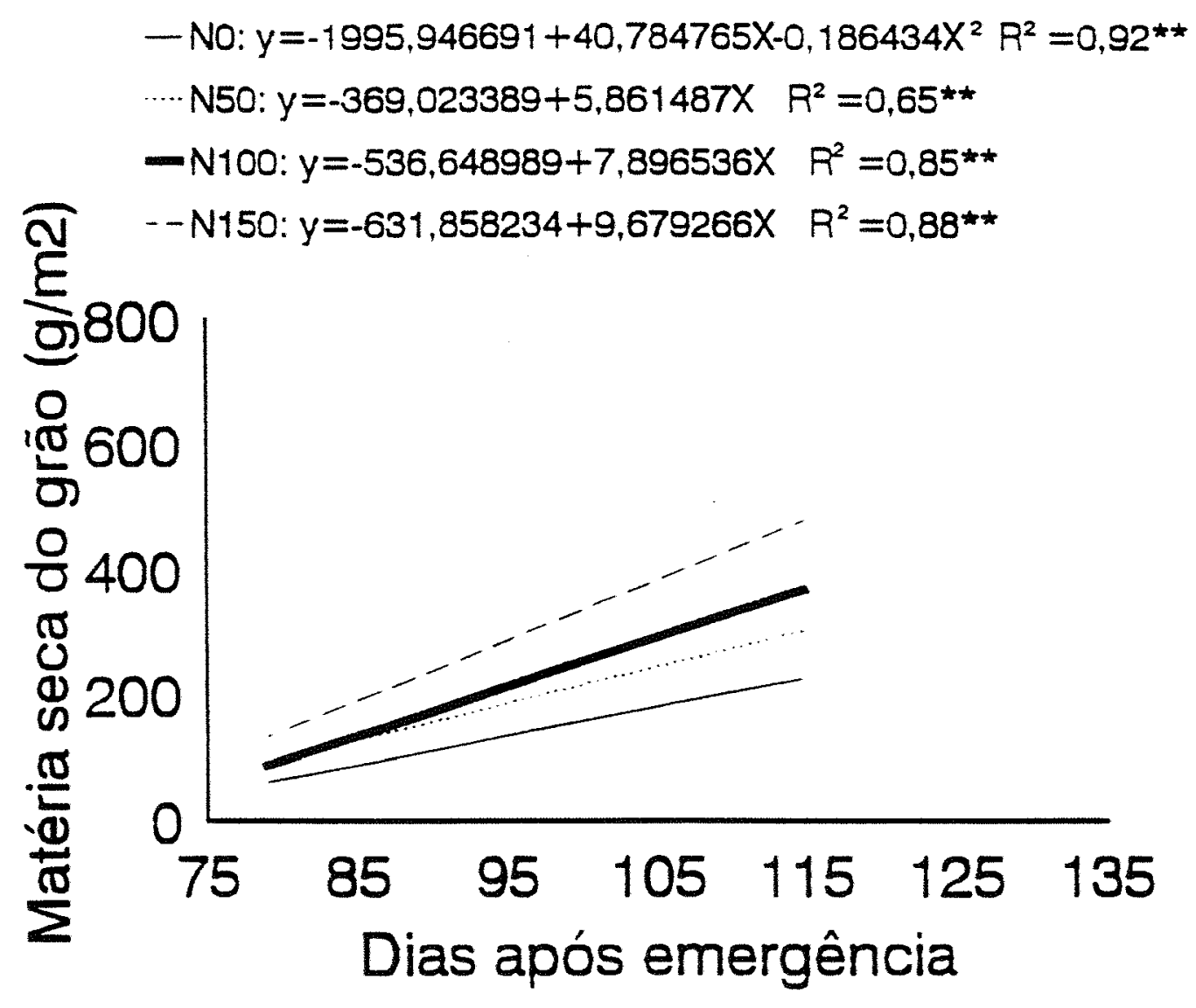

Figura 9. Acumulo da matéria seca do grão em cultivar de milho de ciclo superprecoce $(c 3=P 3072)$ e quatro niveis de nitrogênio. Piracicaba, SP. 1993. 


\section{DISCUSSÃO}

Para efeito de discussão, os parâmetros serão apresentados em dois grupos, ou seja, aqueles relacionados ao crescimento de plantas e outros relativos à produção.

\subsection{Crescimento de plantas}

\subsubsection{Altura de plantas}

Pelas médias dos cultivares, verificou-se quanto a altura das plantas, que os maiores incrementos no desenvolvimento deste parâmetro, foram observados, no tratamento correspondente a maior dose de nitrogênio.

o comportamento diferencial entre os cultivares, quanto a resposta ao nitrogênio, pode ser atribuido, em parte pela época de aplicação 
deste nutriente, a qual foi coincidente com menor disponibilidade de água, sobretudo no que conceme à segunda aplicação (Apêndice l).

Constatou-se que, mesmo nas doses mais altas, os valores médios obtidos para altura da planta foram inferiores aos que têm sido aprocontadoc poloc hibridoc $X L 380$, BR 201 - P3072. No entanto, aposar das condiçōes climáticas não muito favoráveis, observou-se satisfatónio crescimento das plantas, tendo em vista que os hibridos apresentaram uma altura média de $1,87 \mathrm{~m}$; com exceçăo feita ao cultivar superprecoce.

\subsubsection{Indice de área foliar (IAF)}

As observações referentes a este parâmetro, foram realizadas no período de florescimento de cada cultivar, no qual o IAF é considerado máximo, segundo (TOLLENAAR, 1977).

Para o indice de área foliar, o cultivar de ciclo normal (c1) apresentou melhor resposta $(3,05)$, seguido dos cultivares precoce e superprecoce $\operatorname{com} 2,79$ e 2,39, respectivamente. O baixo valor verificado da área foliar, provavelmente, foi devido, ao cultivo do milho em época apresentando condições adversas, ou seja, época designada de "safrinha", objeto de estudo do presente experimento. Tal fato corrobora as afirmaçòes emitidas por DURĀES (1993) o qual verificou semelhante comportamento entre os hibridos estudados. 
Ainda, o incremento dos niveis de nitrogênio propiciou 0 aumento do indice de área foliar, ratificando os resultados obtidos por PEREIRA et al. (1981). Esses autores evidenciaram, que a incorporação de nitrogênio ao solo, determinou melhor desenvolvimento das plantas, refietindo significativamente no aumento do IAF.

\subsubsection{Somatória calórica}

Nas condiçōes adversas em que o milho fol semeado, verificou-se redução do número das unidades de calor, da emergência até o florescimento; valores estes inferiores aos que tem sido apresentados para os cultivares XL380, BR201, ou seja, 915 e 855 U.C., respectivamente. Contudo, ligeiro aumento no acúmulo de unidades de calor foi verificada para o P3072, que apresentou 812 U.C., nas condições do experimento. Tal comportamento foi verificado por DAYNARD (1972) examinando o efeito do ambiente sobre o comprimento do intervalo da emergência e fiorescimento até a formação da camada negra, calculado em graus-dia. Esse mesmo autor, constatou que 0 atraso da semeadura resultou no aumento do número da unidade de calor acumulado da semeadura até o florescimento e uma redução na unidade de calor acumulada do florescimento até a maturidade fisiológica. 


\subsection{Componentes da produção}

A produção de grãos aumentou em função das doses crescentes de nitrogénio, o que confirma os resultados obtidos por WARREN et al (1980), BALKO \& RUSSELL (1980) e TSAl et al. (1984), que verificaram o incremento na produção de grãos em decorréncia do acréscimo nas doses de nitrogênio.

Assim, estando o peso de espiga, relacionado diretamente com a produção de grãos, verificou-se que as maiores produções de espigas e de grãos, foram obtidas nas parcelas com maior quantidade de nitrogênio aplicada (150 kg/ha de N), nos três cultivares avaliados.

Entre os cultivares, o de ciclo precoce (c2) produziu maior rendimento de grãos, que o superprecoce (c3) ocupando posição intermediảria, o cultivar de ciclo normal (c1). Estes resultados apresentam concordáncia com os obtidos no ensaio realizado por DURÃES (1993), em condiçōes semelhantes de clima e solo. Da mesma forma, corroboram as observaçöes de GERAGE \& BIANCO (1987), os quais relataram que os germoplasmas tidos como superprecoce, devem ser evitados no cultivo do milho na época da "safrinha".

Analisando a variável doses de $\mathrm{N}$, verificou-se que a mesma não diferiu estatisticamente, devido ao período desfavorável ao uso da adubação nitrogenada, apresentando a disponibilidade de água como fator limitante. Assim, 
evidencia-se no apêndice II que o peso de grãos, no nivel 3 de nitrogênio (150 $\mathrm{kg} / \mathrm{ha}$ ) foram piores para os cultivares tardio e superprecoce, quando comparado com o nivel 0 de nitrogênio para o cultivar precoce, mostrando-se que na época de safrinha a interação genótipo-ambiente assume acentuada importância.

Com relação ao número de espigas por planta ${ }_{\mathrm{r}}$ em todas as doses de nitrogênio, o cultivar precoce (c2), mostrou-se mais prollfero e, portanto, mais tolerante às condições adversas de semeadura, principalmente estresse hidrico, alta temperatura e ocorrência de pragas e doenças. Na ausência de nitrogênio em cobertura, os cultivares que apresentaram maior exigência por esse nutriente resultaram em menor número de espigas por planta, sendo menor para o cultivar superprecoce (c3) e, intermediário, para o cultivar de ciclo normal (c1).

Quanto ao parâmetro comprimento da espiga (CES), os cultivares de ciclo normal (c1) e precoce (c2), apresentaram maior tamanho de espiga, em funçäo do aumento das doses de nitrogênio aplicadas. Todavia, o maior incremento absoluto ocorreu no intervalo de 0 a $50 \mathrm{~kg} / \mathrm{ha}$ de nitrogênio.

Os maiores indices de rendimento proporcionado pelo uso do nitrogênio pode ser, também, reflexo do efeito deste nutriente sobre o aumento do comprimento da espigas e do nümero de espigas por plantas, conforme relatado por BALKO \& RUSSELL (1980) e KAMPRATH et al. (1982). 


\subsubsection{Acúmulo de matéria seca dos gráos}

Para obtenção da duração do periodo de enchimento de grãos, procurou-se confrontar com os resultados obtidos por DAYNARD et al. (1971) o qual considerou o período de formação do grăo, começando entre 7 e 14 dias aproximadamente, após o florescimento. $\bar{A}$ determinaçăo da formaçăo da camada negra, foi obtida mediante observações periodicas, nos 40 dias após o forescimento, destacando-se grăos da parte mediana da espiga, conforme metodologia descrita por KOLLER (1972).

Ao se comparar o número de dias entre o florescimento e a formação da camada negra, verificou-se relativa constância, mesmo entre cultivares distintos, confirmando as afirmações de FANCELLI (1986).

Todavia, na literatura estrangeira, diversos trabaihos mostraram que genótipos de milho difeniram na duração da fase reprodutiva, sendo obtidos por alguns pesquisadores os seguintes periodos: 54 a 64 dias, HALLAUER \& RUSSELL (1962); 53 a 61 dias, HILLSON \& PENNY (1965) e 49,2 a 62,6 dias, DAYNARD \& DUNCAN (1969).

Assim, analisando o comportamento das respostas a doses de nitrogênio, constatou-se uma tendência do peso da matéria seca do grão aumentar, com o acréscimo do nitrogênio ao solo. Esse incremento foi mais marcante no cultivar de ciclo precoce (c2), sendo menor no cultivar superprecoce 
(c3) e, intermediário, no cultivar normal (c1). Esta resposta da aplicação do nitrogênio, provaveimente ocorreu devido ao parcelamento da adubação nitrogenada em cobertura. 


\section{CONCLUSÕES}

Os resultados obtidos permitiram concluir que:

a) Para a semeadura do milho na época de "safrinha": a interação genótipo-ambiente, assume acentuada importância.

b) $\mathrm{Na}$ "safrinha", hibridos que apresentam longo periodo de enchimento de grăos e acúmulo uniforme de matéria seca no periodo, proporcionam meihor rendimento e produçăo.

c) A adubação nitrogenada em cobertura, em condiçōes de "safrinha" não resulta em substancial acréscimo no indice de área foliar e no rendimento dos hibridos estudados, sobretudo para o cultivar superprecoce. 


\section{REFERÊNCIAS BIBLIOGRÁFICAS}

BALKO, L.G. \& RUSSELL, W.A. Response of maize inbred lines to $N$ fertilizer. Agronomy Joumal, Madison, 72:723-8, Sept./Oct. 1980.

CARTER, M.W. \& PONELEIT, C.G. Black layer maturity and filing period variation among inbred lines of corn (Zea mays L). Crop Sclence, Madison, 13:436-9, July/Aug. 1973.

COSTA, JM.N. da; ANTUNES, F.Z.; SANTANA, D.P. Zoneamento agroclimático e pianejamento agricola. Informe Agropecuário, Belo Horizonte, 12(138):14-7, jun. 1986. 
CROSBIE \& MOCK, J.J. Changes in physiological traits associated with grain yield improvement in three maize breeding programs. Crop Science, Madison, 21:255-8, 1981.

DAYNARD, T.B. Relatlonships among black layer formation, grain molsture percentage, and heat unit accumulation in corn. Agronomy Joumal, Madison, 64:716-9, Nov/Dec. 1972.

DAYNARD, T.B.\& DUNCAN, W.G. The black layer and grain maturity in com. Crop Science, Madison, 9:473-6, July/Aug. 1969.

DAYNARD, T.8. \& KANNENBERG, L.W. Relationships between length of the actual and effective grain filling periods and the grain yield of com. Canadian Joumal of Plant Sclence, Ottawa, 56: 237-42, Apr. 1976.

DAYNARD, T.B.; TANNER, J.W.; DUNCAN, W.G. Duration of the grain filling period and its relations to grain yield in com Zea mays $L$. Crop Sclence, Madison, 11:45-8, Jan./Feb. 1971. 
DUARTE, A.P.; ALLIPRANDINI, L.F ; SAWAZAKI, E.; KANTHACK, R.A.D. Avaliação de cultivares de milho "safrinha" no vale Paranapanema. In: CONGRESSO NACIONAL DE MILHO E SORGO, 20., Goiânia, 1994. Resumos. Goiânia, Associação de Milho e Sorgo, 1994. p.91.

DUNCAN, W.G. \& HATFIELD, A.L. A method for measuring the daiiy growth of corn kemels. Crop Science, Madison, 4:550-1, 1964.

DUNCAN, W.G.; HATFIELD, A.L.; RAGLAND, J.L. The growth and yield of com. II. Daily growth of corn kernels. Agronomy Joumal, Madison, 57:221-3, 1965.

DURÃES, F.O.M. Fatores ecofisiológicos afetando o comportamento de milho em semeadura tardia (safrinha) no Brasil Central. Piracicaba, 1993. 91p. (Doutorado - Escola Superior de Agricultura "Luiz de Queiroz"USP).

ESTEVES, A.;.PEREIRA, E.B.C.; RUSCHEL, R. Avaliação de caracteristicas agrônomicas em cultivares de milho (Zea Mays) introduzidas, no plantio de safrinha. In: CONGRESSO NACIONAL DE MILHO E SORGO, 20., Goiânia, 1994. Resumos. Goiânia, Associação Brasileira de Milho e Sorgo, 1994. p.36. 
FANCELLI, A.L. \& LIMA, U.A. Milho; produção, pré-processamento e transformaçăo agroindustrial. São Paulo, Secretaria da Indústria, Comércio, Ciência e Tecnologia, 1986. 112p. (Extensão Agroindustrial, 5).

FRANCIS, C.A.; RUTGER, J.N.; PALMER, A.F.E. A rapid method for plant leaf area estimation in maize (Zea Mays L.). Crop Science, Madison, $9: 537-9,1969$

GILMORE, E.C. \& ROGERS, J.S. Heat units as a method of measuring maturity in com. Agronomy Journal, Madison, 50:611-5, 1958.

GUNN, R.B. \& CHRISTENSEN, R. Maturity relationships among early to late hybrids of com (Zea mays L.). Crop Science, Madison, 5:299$302,1965$.

HALLAUER, A.R. \& RUSSELL, W.A. Estimates of maturity and its inheritance in maize. Crop Sclence, Madison, 2:289-94, 1962.

HANWAY, J.J. Corn growth and composition in relation to soil fertility: I. Growth of different plant parts and relation between leaf weight and grain yield. Agronomy Joumal, Madison, 54:145-8, 1962. 
HANWAY, J.J. \& RUSSELL. W.A. Dry-matter accumulation in com (Zea mays L.) plants: comparisons among single-cross hybrids. Agronomy Journal, Madison, 61: 947-51, Nov.JDec. 1969.

HILLSON, M.T. \& PENNY, L.H. Dry matter accumulation and moisture loss during maturation of com grain. Agronomy Joumal, Madison, 57:150$3,1965$.

JOHNSON, D.R. \& TANNER, J.W. Calculation of the rate and duration of grain filling in corn (Zea mays L.). Crop Science, Madison, 12:485-6, July/Aug. 1972.

KAMPRATH, E.J.; MOLL, R.H.; RODRIGUEZ, N. Effects of nitrogen fertilization and recurrent selection on performance of hybrid populations of com. Agronomy Joumal, Madison, 74:955-8, 1982.

KOLLER, O.L. Maturação îsiológica e variaçōes de matéria seca e umidade, durante o periodo de formação dos grăos, em seis cultivares de milho. Porto Alegre, 1972. 138p. (Mestrado - Faculdade de Agronomia/Universidade Federal do Rio Grande do Sul). 
MAGALHĀES, P.C.; RESENDE, M.; OLIVEIRA, A.C. de; DURÃES,F.O.M.; SANS, L.M.A. Caracterização da planta de milho. In: EMPRESA BRASILEIRA DE PESQUISA AGROPECUÁRIA. Centro Nacional de Pesquisa de Milho e Sorgo. Relatório técnlco anual 1992-1993. Sete Lagooo, 1804. p.166-7.

MCGARRAHAN. J.P. \& DALE, R.F. A trend toward a longer grain filling period for corn: A case study in Indiana. Agronomy Journal, Madison, 76:518-22, Juhy/Aug. 1984.

MEDEIROS, J.B, de \& SILVA, P.R.F. de. Efeitos de níveis de nitrogênio e densidades de plantas sobre $\circ$ rendimento de grãos $e$ outras caracteristicas agronômicas de duas cuttivares de mitho (Zea mays L.). Agronomia Sulriograndense, Porto Alegre, 11(2): 227-49, 1975.

OLIVEIRA, M.D.X. de; ANDRADE, J.A.C.; ARF, O; PASTANA, A.K.M.P. Estudos de épocas de semeadura e ciclo de cultivar de milho safrinha na região Sudeste do Mato Grosso de Sul. In: CONGRESSO NACIONAL DE MILHO E SORGO, 20., Goiânia, 1994. Resumos. Goiânia, Associação Brasileira de Milho e Sorgo, 1994. p.177. 
PEASLEE, D.E.; RAGLAND, J.L.; DUNCAN, W.G. Grain filling period for corn as influenced by phosphorus, potassium, and the time of planting. Agronomy Journal, Madison, 63:561-3, July/Aug. 1971.

PEASLEE, D.E. Effects of nitrogen, phosphorus, and potassium nutrition on yield, rates of kemel growth and grain filling periods of two com hybrids. Communication in Soll Science \& Plant Analysis, New York, $8(5): 373-89,1977$.

PEREIRA, P.A.A.; BALDANI, J.l; BLANA, R.A.G.; NEYRA, C.A. Assimilação e transiocação de nitrogênio em relação à produção de grãos e proteínas em milho (Zea mays L.). Revista Brasileira de Clência do Solo, Campinas, 5: 28-31, 1981.

RAGLAND, J.L.; HATFIELD, A.L; BENOIT, G.R. The growth and yield of com. 1. Microclimatic effects on the growth rate. Agronomy Joumal, Madison, 57:217-20, 1965.

REDDY, V.M. \& DAYNARD, T.B. Endosperm characteristics associated with rate of grain filling and kemel size in com. Maydlca, Bergamo, 28:339$55,1983$. 
RENCH, W.E. \& SHAW, R.H. Black layer development in com. Agronomy Joumal, Madison, 63:303-5, Mar./Apr. 1971.

SAWAZAKI, E; DUARTE, A.P.; MARUNO, J.; BORTOLETTO, N.; GALLO, P.B.; OARCIA, L.L.C.; VONTINHO, R.G.; SILVA, J.G.M.; BIANCHIBI, M.T.; SALZEDAS, M.L.V.M; DONA, S. Avaliação de cultivares de milho "safrinha" no Estado de São Paulo. In: SEMINÁRIO SOBRE A CULTURA DO MILHO "SAFRINHA, 2., Assis, 1994. Resumos. Assis, IAC, 1994. p.41-8.

SAYRE, J.D. Mineral accumulation in com. Plant Physiology, Bethesda, 23(3): $267-81,1948$

SHAW, R.H. \& THOM, H.C.S. On the phenology of field com, silking to maturity. Agronomy Joumal, Madison, 43: 541-6, 1951.

TEIXEIRA, $M$. do $R$. de $O$. Comportamento de cultivares de milho semeadas após o periodo normal. In: CONGRESSO NACIONAL DE MILHO E SORGO, 20., Goiânia, 1994. Resumos. Goiânia, Associação Brasileira de Milho e Sorgo, 1994. p.238. 
TOLLENAAR, M. Sink-source relationships during reproductive development in maize. A review. Maydica, Bergamo, 22(2):49-75, 1977.

TSAI, C.Y.; HUBER, D.M.; GLOVER, D.V.; WARREN, H.L. Relationship of $N$ deposition to grain yield and $N$ response of three maize hybrids. Crop Sclence, Madison, 24:277-81, Mar./Apr. 1984.

TSUNECHIRO, A. Produção e comercialização de milho. In: SEMINÁRIO SOBRE A CULTURA DO MILHO "SAFRINHA", 2., Assis, 1994. Resumos. Assis, IAC, 1994, p.1-5.

WARREN, H.L.; HUBER, D.M.; TSAI, C.Y.; NELSON, D.W. Effect of nitrapyrin and $N$ fertilizer on yield and mineral composition of com. Agronomy Joumal, Madison, 72:729-32,1980. 


\section{APÉNDICE}


Apêndice I. Dados meteorológicos, obtidos durante o periodo experimental, referente ao periodo de Janeiro a Junho de 1993.

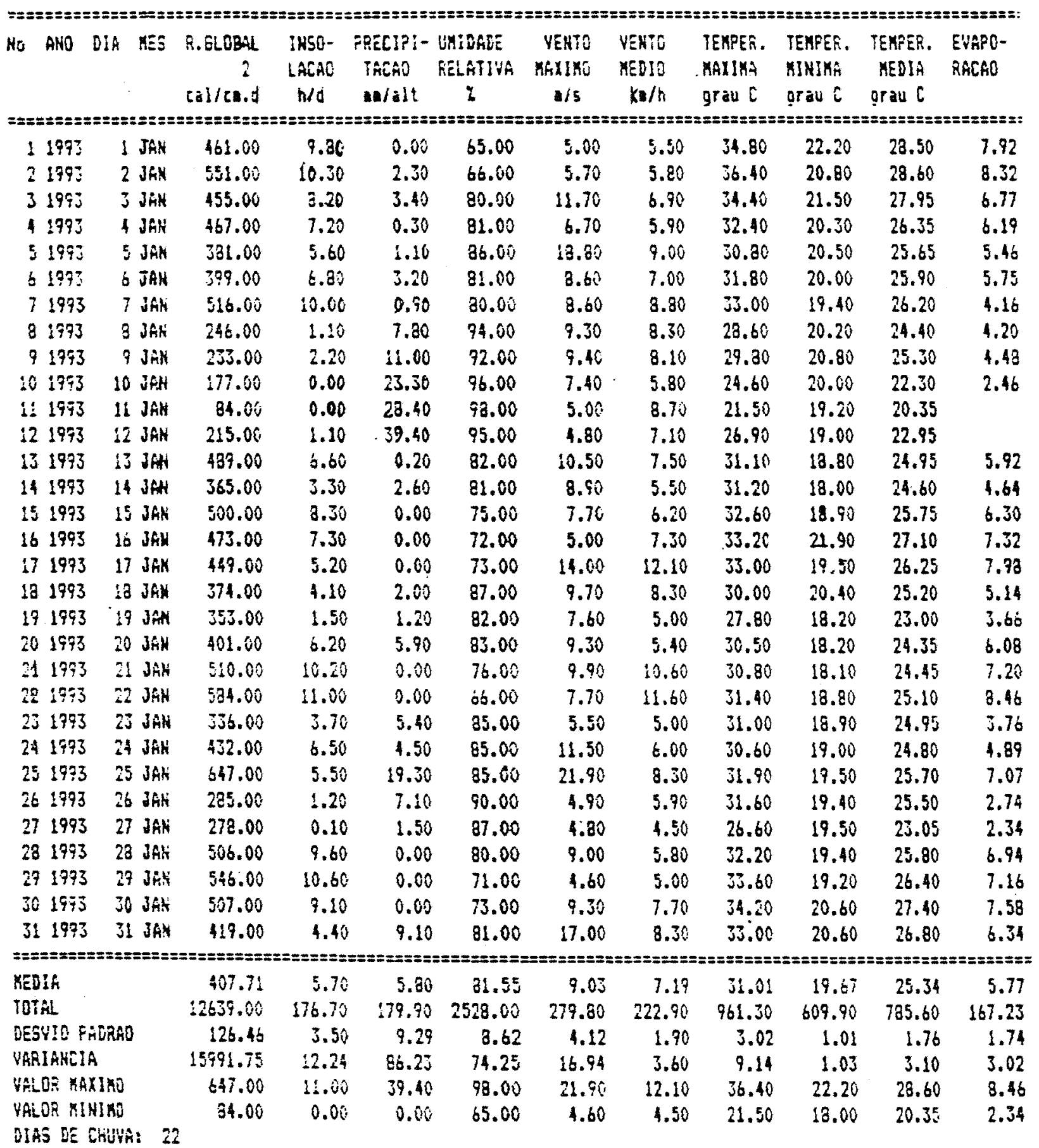


Apêndice I. Dados meteorológicos, obtidos durante o período experimental, referente ao periodo de Janeiro a Junho de 1993 . (Continua)

\begin{tabular}{|c|c|c|c|c|c|c|c|c|c|c|c|}
\hline KO ANO & DIA MES & $\begin{array}{c}\text { R.6LOBf: } \\
2 \\
\text { col/ca.t } \\
:=:=====\end{array}$ & $\begin{array}{l}\text { INSE- } \\
\text { LACAC } \\
n / E \\
==:===\end{array}$ & 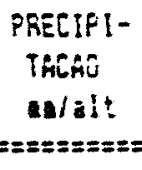 & $\begin{array}{c}\text { BNIOAEE } \\
\text { BELATIYH } \\
\vdots\end{array}$ & $\begin{array}{c}\text { Yentí } \\
\text { Xerlino } \\
\text { I/s } \\
=:=:=:==\end{array}$ & 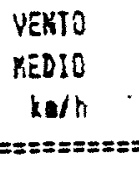 & 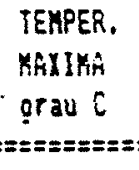 & $\begin{array}{l}\text { TEMPER. } \\
\text { KINIMÂ } \\
\text { orau C } \\
\text { :=:=:=:== }\end{array}$ &  & $\begin{array}{l}\text { EVAPO- } \\
\text { GACAO }\end{array}$ \\
\hline 321993 & I FEY & $348 . \hat{v} \hat{V}$ & $2.1 \hat{v}$ & 0.00 & 82.00 & 5.30 & 6.70 & 30.80 & 19.00 & 24.90 & 4.08 \\
\hline 331993 & $2 \mathrm{FEH}$ & 369.00 & 4.30 & 9.50 & 86.00 & 15.30 & 7.20 & 31.80 & 18.70 & 25.25 & 5.66 \\
\hline 341793 & J FEY & 258.00 & $0.6 \hat{v}$ & 12.70 & 89.00 & 10.40 & 6.60 & 28.00 & 18.90 & 23.45 & 5.66 \\
\hline 351993 & $4 \mathrm{FEV}$ & 335.00 & 2.40 & 5.70 & 88.00 & 6.70 & 9.30 & 27.40 & 19.10 & 23.25 & 2.68 \\
\hline $36 \quad 1993$ & $5 \mathrm{FEV}$ & $134.0 \hat{v}$ & 0.50 & $2.3 \hat{v}$ & 34.00 & 6.00 & 6.80 & 23.40 & 19.00 & 21.20 & 0.66 \\
\hline 371993 & 6 FEY & 333.00 & 2.60 & 0.60 & 87.00 & 7.50 & 8.20 & 28.80 & 19.50 & 24.15 & 3.00 \\
\hline 381993 & $7 \mathrm{FEY}$ & 327.00 & 3.00 & 4.50 & $87.6 \hat{0}$ & 6.00 & 3.70 & 30.20 & 20.70 & 25.45 & 4.10 \\
\hline 371993 & 8 FEY & 399.00 & 5.30 & 5.70 & 24.00 & 7.80 & 9.10 & 31.70 & 20.20 & 25.95 & 5.94 \\
\hline 401993 & q FEY & 373.00 & 2.70 & 4.40 & 84.60 & 6.00 & 8.20 & 29.60 & 20.40 & 25.00 & 4.84 \\
\hline 411993 & $10 \mathrm{FEY}$ & 221.00 & 0.30 & 12.80 & 95.00 & 4.80. & 7.00 & 27.20 & 20.00 & 23.60 & 3.36 \\
\hline 421973 & $11 \mathrm{FEV}$ & 326.00 & 3.20 & 37.20 & 90.00 & 10.00 & 8.40 & 29.50 & 20.80 & 25.15 & \\
\hline 431993 & $12 \mathrm{FEr}$ & 471.00 & 7.60 & 0.50 & 85.00 & 16.30 & 8.60 & 29.80 & 13.80 & 24.30 & 5.63 \\
\hline 441993 & $13 \mathrm{FEV}$ & 524.00 & 10.00 & 0.00 & 79.00 & 4.20 & 6.90 & 31.60 & 16.60 & 24.10 & 5.78 \\
\hline 451993 & $14 \mathrm{FEV}$ & 377.00 & 6.80 & $30.0 \hat{0}$ & 36.00 & 9.60 & 10.70 & 29.60 & 19.00 & 24.30 & 5.88 \\
\hline 4t 1993 & $15 \mathrm{FEV}$ & 317.00 & 1.80 & 19.90 & 88.00 & 5.60 & 7.90 & 27.60 & 19.40 & 23.50 & 5.12 \\
\hline 471993 & $16 \mathrm{FEV}$ & 350.00 & 2.80 & 21.30 & 28.00 & 12.80 & 7.50 & 28.20 & $19: 20$ & 23.70 & \\
\hline 481993 & 17 FEV & 272.00 & 1.00 & 5.00 & 90.00 & 4.90 & 4.60 & 26.30 & 20.00 & 23.40 & 6.48 \\
\hline 491993 & $18 \mathrm{FEV}$ & 213.00 & 0.20 & 0.00 & 90.00 & 5.60 & 6.10 & 26.20 & 19.20 & 22.70 & 2.46 \\
\hline $501993^{\circ}$ & 17 FEV & 450.00 & 7.10 & 24.40 & 23.00 & 12.30 & 8.40 & 31.40 & 18.00 & 24.70 & \\
\hline 511993 & $20 \mathrm{FE}:$ & 290.00 & 4.30 & 8.20 & 84.00 & 8.90 & 4.80 & 27.20 & 18.00 & 22.60 & 9.14 \\
\hline 521993 & $21 \mathrm{FEM}$ & 333.00 & 0.20 & 0.30 & 22.00 & 7.00 & 7.20 & 29.00 & 18.40 & 23.70 & 4.04 \\
\hline 531993 & 22 FEV & 216.00 & 1.70 & 20.10 & 88.00 & 4.40 & 6.60 & 25.20 & 18.00 & 21.60 & \\
\hline 541993 & $23 \mathrm{FEV}$ & 234.00 & 0.90 & 3.30 & 37.09 & 4.60 & 5.00 & 26.20 & 16.80 & 21.50 & 1.96 \\
\hline 551993 & 24 FEU & 351.00 & 5.10 & 0.00 & $35.0 \hat{0}$ & 4.20 & 6.20 & 28.40 & 18.40 & 23.40 & 3.70 \\
\hline 561993 & $25 \mathrm{FEV}$ & 530.00 & 9.20 & 0.00 & .70 .00 & 3.40 & 8.10 & 30.60 & 17.00 & 23.80 & 6.50 \\
\hline 571993 & $26 \mathrm{FEV}$ & 425.00 & 8.00 & 0.00 & 70.00 & 3.60 & 9.30 & 30.20 & 17.20 & 23.70 & 6.40 \\
\hline 531993 & $27 \mathrm{FEV}$ & 318.00 & 4.70 & 3.50 & 84.00 & 6.80 & 5.00 & 30.40 & 18.00 & 24.20 & 2.26 \\
\hline 591993 & $28 \mathrm{FEY}$ & 405.00 & 6.10 & 0.00 & 78.00 & 4.70 & 4.40 & 29.80 & 18.20 & 24.00 & 5.66 \\
\hline 601993 & $29 \mathrm{FEH}$ & & & & & & & & & & \\
\hline
\end{tabular}

\begin{tabular}{|c|c|c|c|c|c|c|c|c|c|c|}
\hline KEDIA & $340.4 j$ & 3.73 & 3.29 & 85.10 & 7.71 & $\begin{array}{r}7.22 \\
703.70\end{array}$ & $\begin{array}{r}28.81 \\
306.00\end{array}$ & $\begin{array}{r}10.80 \\
=25.50\end{array}$ & 23.81 & $\begin{array}{r}4.62 \\
10.99\end{array}$ \\
\hline $\begin{array}{l}\text { TOTAL } \\
\text { SESUIO DANgeO }\end{array}$ & 9532.00 & $\begin{array}{r}104.50 \\
2.82\end{array}$ & 232.10 & 2385.00 & 215.90 & $\begin{array}{r}203.70 \\
157\end{array}$ & $\begin{array}{r}306.00 \\
2.06\end{array}$ & 526.50 & 666.55 & $\begin{array}{l}0.89 \\
1.85\end{array}$ \\
\hline $\begin{array}{l}\text { DESVIO PADRAO } \\
\text { VARIAMCIA }\end{array}$ & $\begin{array}{r}91.69 \\
8407.03\end{array}$ & $\begin{array}{l}2.82 \\
7.98\end{array}$ & $\begin{array}{r}10.09 \\
001.85\end{array}$ & $\begin{array}{r}3.65 \\
31.93\end{array}$ & $\begin{array}{r}3.27 \\
10.65\end{array}$ & $\begin{array}{l}1.57 \\
2.47\end{array}$ & $\begin{array}{l}2.06 \\
4.24\end{array}$ & $\begin{array}{l}1.11 \\
1.22\end{array}$ & $\begin{array}{l}1.14 \\
1.29\end{array}$ & $\begin{array}{l}1.85 \\
3.44\end{array}$ \\
\hline VALOR KAXINO & 530.00 & 10.00 & 37.20 & 95.00 & 16.30 & 10.70 & 31.80 & 20.80 & 25.95 & 9.14 \\
\hline GLOR XINIME & 134.00 & 0.20 & 0.00 & 70.00 & 4.20 & 4.40 & 23.40 & 16.60 & 21.20 & 0.66 \\
\hline
\end{tabular}


Apêndice I. Dados meteorológicos, obtidos durante o periodo experimental, referente ao periodo de Janeiro a Junho de 1993 . (Continua)

\begin{tabular}{|c|c|c|c|c|c|c|c|c|c|c|c|}
\hline No AHO & DIA MES & $\begin{array}{c}\begin{array}{c}\text { R. GLOBÁL } \\
2 \\
\mathrm{cal} / \mathrm{ca} .6\end{array} \\
==:======\end{array}$ & $\begin{array}{l}\text { IHSO- } \\
\text { LACAO } \\
\text { h/o } \\
=:=:==:=\end{array}$ & $\begin{array}{l}\text { ERECIPI- } \\
\text { TACAC } \\
\text { m/alt } \\
=:=:=:==\end{array}$ & $\begin{array}{l}\text { - URIGALE } \\
\text { RELATIVA } \\
\mathrm{x} \\
\text { : }\end{array}$ & $\begin{array}{c}\text { VENTO } \\
\text { XAXIMO } \\
\text { I/5 } \\
=:=:==2\end{array}$ & $\begin{array}{l}\text { VENTO } \\
\text { REDIO } \\
\text { KE/h } \\
=:=:=:=\end{array}$ & $\begin{array}{l}\text { TEXPER. } \\
\text { KAXIMA } \\
\text { grau C } \\
\text { =:=:=:=:= }\end{array}$ & $\begin{array}{l}\text { TEKPER. } \\
\text { MINIKA } \\
\text { grau } 6 \\
\text { :=:==:==:= }\end{array}$ & $\begin{array}{l}\text { TEMPER. } \\
\text { MEDIA } \\
\text { grau } 6 \\
===:= \pm==: 2\end{array}$ & $\begin{array}{l}\text { EVAPO- } \\
\text { RACAD }\end{array}$ \\
\hline $6: 1973$ & I KAR & 274.00 & 2.00 & 0.00 & 84.00 & 10.90 & 6.10 & 30.20 & 20.00 & 25.10 & 3.96 \\
\hline 621993 & 2 MAR & & & & & & & & & & 5.76 \\
\hline 631973 & 3 MAR & 458.00 & 8.10 & & & 5.40 & 6.10 & & 19.20 & & 6.58 \\
\hline 641993 & 4. IAR & 426.00 & 8.50 & & & 8.00 & 9.70 & 31.20 & 19.10 & .30 & 6.34 \\
\hline 651993 & 5 KAR & 279.00 & 1.80 & 0.00 & 84.00 & 5.70 & 8.50 & 28.40 & 18.80 & 23.60 & 3.56 \\
\hline te 1993 & 6 NAR & 51 & 10.20 & & 67 & 5.00 & 5.80 & 33.40 & 18.00 & 25.7 & 6.14 \\
\hline $6 i 1993$ & 7 KAK & 492 & 9.00 & & & & 4.30 & & 17.60 & 25.76 & 3.14 \\
\hline$=21993$ & a MAF & & 9.00 & 0. & & & & & 18.40 & 26.20 & 6.56 \\
\hline 671993 & $7 \mathrm{KAR}$ & & 10.70 & & & & & & 18.20 & & 7.10 \\
\hline $70 \quad 1973$ & 10 KAR & & 9.60 & & & & & 33.80 & 19.00 & 26.40 & 6.60 \\
\hline 711993 & $11 n$ & & 8.30 & & & & 7 & .60 & 19.00 & 25.80 & 6.08 \\
\hline 721993 & 12 KAR & 4 & 10.20 & & & & & 00 & 19.20 & 26.10 & 7.04 \\
\hline 731993 & IJ KAR & 4 & 10.20 & & & & & .00 & 17.60 & 24.90 & 8.10 \\
\hline 7419 & 14 KAR & & 7.60 & & & & &  & .60 & 25.60 & 7.12 \\
\hline 7519 & $15 x$ & & 6 & & & & & 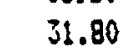 & 10 & 24.95 & 3.66 \\
\hline 7618 & $16 x$ & & 5. & & & & & & 40 & 24.0 & 4.60 \\
\hline 7719 & $17 x$ & & 7.8 & & & & & & .80 & 24. & 6.46 \\
\hline 7215 & $18 n$ & & 5.4 & & & & & & .80 & 25.10 & 3.68 \\
\hline 7919 & $19 \%$ & & 6 & & & 17 & & & 90 & 23 & \\
\hline 3018 & $20 x$ & & 4 & & & & 12 & & 7.40 & 23. & 5.70 \\
\hline Si: & $21 n$ & & & & & & & & .80 & 22 & 2.82 \\
\hline 8219 & $22 x$ & & & & & & & & 1.40 & 22 & 2.00 \\
\hline 851 & $23 \%$ & & & & & & & & 26 & 24. & \\
\hline $5+19$ & 24 & & & & & & & & 18.4 & 24. & 4.74 \\
\hline 351 & $25 r$ & & & & & & & . & 19.0 & 23 & 2.18 \\
\hline as 1 & $26 n$ & & & & & & & & 18 & 23. & 2.60 \\
\hline $87:$ & $27 \mathrm{~K}$ & & & & & & & 30 & 17 & 24.15 & 4.83 \\
\hline $83:$ & $28 n$ & & & & & & & 30 & 18 & 24.70 & 3.25 \\
\hline $3 \div 1$ & $29 \mathrm{~K}$ & & & & & & & & 18 & 22.35 & 2.06 \\
\hline 901 & 30 $\mathrm{K}$ & & 7. & & & 6. & & 29.60 & 19.80 & 24.70 & 5.2 \\
\hline $8: 19$ & 314 & 37 & 6.90 & 40. & $7 i$. & 6. & 6. & 30.90 & 18.20 & 24.55 & \\
\hline$=-\infty$ & & & & & & & & & & & \\
\hline KEDIF & & & 6.27 & 5.03 & & & & 30.91 & 18. & 24.73 & 4.8 \\
\hline 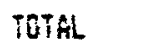 & & & & & & & & & & & 36.24 \\
\hline SE3v10 & ORAO & 87. & , & & ? & 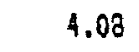 & 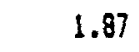 & 2.28 & 0.67 & 1.06 & 1.69 \\
\hline VARI & & & & & & & & & 0. & 5.13 & 2.8 \\
\hline VALO & & & 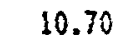 & & & & 12 & 20 & 30 & 6.50 & 7.1 \\
\hline VALQS XIHI & & 157.00 & 0.10 & 0.00 & 65.00 & 2.00 & 2.60 & 25.60 & 17.20 & 22.35 & 2.00 \\
\hline
\end{tabular}

Dัสล DE CHUYA: 12 
Apêndice I. Dados meteoralógicos, obtidos durante o períado experimental, referente ao periodo de Janeiro a Junho de 1993. (Continua)

\begin{tabular}{|c|c|c|c|c|c|c|c|c|c|c|c|}
\hline Ho ANO & OIA KES & $\begin{array}{c}\text { R.GLOBAL } \\
2 \\
\text { Cal/CE. } \\
========\end{array}$ & $\begin{array}{l}\text { IKSO- } \\
\text { LACAO } \\
\text { H/O } \\
======\end{array}$ & 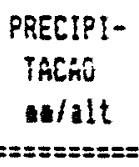 & 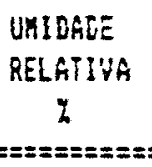 & $\begin{array}{c}\text { VERTO } \\
\text { XAXIKO } \\
1 / 5 \\
\text { =:=:=:= }\end{array}$ & $\begin{array}{r}\text { VENTO } \\
\text { REDIO } \\
\text { ha/h } \\
\text { E=:=-= }\end{array}$ & $\begin{array}{l}\text { TENPEK. } \\
\text { MAXIKA } \\
\text { ọraU C } \\
\text { :=:=:= }\end{array}$ & $\begin{array}{l}\text { TENPER. } \\
\text { NIHIMA } \\
\text { Orau } ~ \\
=== \pm= \pm=\end{array}$ & $\begin{array}{c}\text { TEKPER. } \\
\text { MEDIA } \\
\text { graU C } \\
\text { =:=:=:=.: }\end{array}$ & $\begin{array}{l}\text { EVAPO- } \\
\text { RACAO }\end{array}$ \\
\hline 721993 & $1 \mathrm{ABR}$ & 129.00 & 0.20 & 2.30 & 95.00 & 3.40 & 4.80 & 24.80 & 19.20 & 22.00 & 0.56 \\
\hline 931993 & 2 ABR & & 1.20 & 0.90 & & & & 26.20 & & 2.75 & 1.58 \\
\hline 941993 & $3 \mathrm{ABR}$ & & 4.80 & 1.30 & 91.00 & 5.40 & 4.00 & 28.70 & 18.60 & 23.65 & 2.82 \\
\hline 951993 & $4 \mathrm{ABR}$ & & 8.70 & 0.00 & 79.00 & 2.90 & 4.70 & 30.50 & 17.30 & 23.90 & 4.84 \\
\hline 751993 & $5 \mathrm{ABR}$ & & 8.70 & 0.00 & 32.00 & 5.30 & 7.30 & 31.81 & $18: 20$ & 25.00 & 5.30 \\
\hline 971993 & 6 AER & & 8.90 & 0.00 & & 6.10 & 6.30 & & & $24.6 j$ & 1.29 \\
\hline 731973 & 7 A8R & & 9.80 & 0.00 & & 5.00 & & & & 25.65 & 5.40 \\
\hline 991993 & O ABR & & 4.10 & & & 21.20 & & & & & 7.71 \\
\hline 1001973 & $7 \mathrm{ABR}$ & & & & & & & & & & 4.86 \\
\hline 011993 & $10 \mathrm{AER}$ & & 8.90 & & & 7.60 & & & & & 4.74 \\
\hline 021993 & $11 \mathrm{ABR}$ & & 8.80 & 0. & & 5.20 & & & & 21.60 & 4.20 \\
\hline 031993 & $12 \mathrm{ABR}$ & & 8.20 & 1. & & 5.00 & & & & 23.95 & 4.50 \\
\hline 041993 & $13 \mathrm{ABR}$ & & 7.40 & 0.00 & & 3.50 & & & & 23.80 & 3.96 \\
\hline 051973 & If $A B A$ & & 6.10 & & & 2. & & & & & 4.09 \\
\hline 061993 & $15 \mathrm{ABR}$ & & 9.10 & & & 3.20 & & & & 24.35 & 4.93 \\
\hline 071993 & If ABR & & 9.70 & & & 7. & & & & 23.60 & 6.00 \\
\hline 021993 & $17 \mathrm{ABR}$ & & & & & & & & & 23.09 & 4.20 \\
\hline 1993 & $18 \mathrm{ABR}$ & & & & & 5. & & 00 & & 23.70 & 4.00 \\
\hline 1019 & $17 \mathrm{~A} 98$ & & & & & & & & & 23.95 & 4.48 \\
\hline 1118 & $20 \mathrm{~A} B \mathrm{R}$ & & 10 & & & & & 30 & & 24.80 & 4.26 \\
\hline 11218 & $21 \mathrm{~A} B \mathrm{R}$ & & 6 & & & & & 80 & 50 & 24.65 & 4.78 \\
\hline 1318 & $22 \mathrm{ABR}$ & & 0 & & & & & & & 65 & 5.26 \\
\hline 141 & $23 \mathrm{ABP}$ & & & & & 4.5 & & 80 & & 22.95 & 3.56 \\
\hline $15199 j$ & $24 \mathrm{~A}$ & & & & & 5. & & 00 & & 22.25 & 3.92 \\
\hline 161 & $.25 \mathrm{~A}$ & & & & & 2. & & 20 & 40 & 21.30 & 4.12 \\
\hline 31718 & $26 \mathrm{~A}$ & & & & & 0 & & 30 & .60 & 21.45 & 3.95 \\
\hline 1181993 & $27 \mathrm{ABR}$ & & & & & -1 & & 60 & 60 & 22.10 & 5.03 \\
\hline 181 & $28 \mathrm{ABR}$ & & & & & 1 & & 0 & & 22.20 & 3.72 \\
\hline 1201 & $27 \mathrm{ABP}$ & & & & & 7. & & 00 & & 22.60 & 4.67 \\
\hline 5211993 & $30 \mathrm{ABE}$ & 3 & 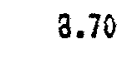 & 0.00 & 74.00 & 4.80 & 6.10 & 30.10 & 15.20 & 22.65 & 4.33 \\
\hline \multicolumn{12}{|c|}{ 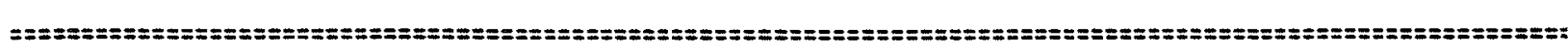 } \\
\hline \multicolumn{2}{|l|}{ KEDIA } & & & & & & & 0,7 & & 979 & \\
\hline \multirow{2}{*}{\multicolumn{2}{|c|}{$\begin{array}{l}\text { TETAL } \\
\text { DESUYO }\end{array}$}} & & & & & & & & & & 30.06 \\
\hline & & & 17 & & & 3.28 & & 1.8 & 1.7 & 1.23 & 1.22 \\
\hline \multicolumn{2}{|l|}{ VARIAHCIA } & & & & & 10.78 & & 3.65 & 3.10 & 1.52 & 1.49 \\
\hline \multicolumn{2}{|c|}{ VALLOR XAXIMO } & & 10.10 & 37.50 & 95.00 & $21.20^{\circ}$ & 10.80 & 32.60 & 17.40 & 25.85 & 7.71 \\
\hline \multicolumn{2}{|c|}{ YALOR YIKIKO } & 129.00 & 0.20 & 0.00 & 69.00 & 2.00 & 4.00 & 24.80 & 13.40 & 21.25 & 0.56 \\
\hline
\end{tabular}


Apêndice I. Dados meteorológicos, obtidos durante o periodo experimental, referente ao periodo de Janeiro a Junho de 1993 . (Continua)

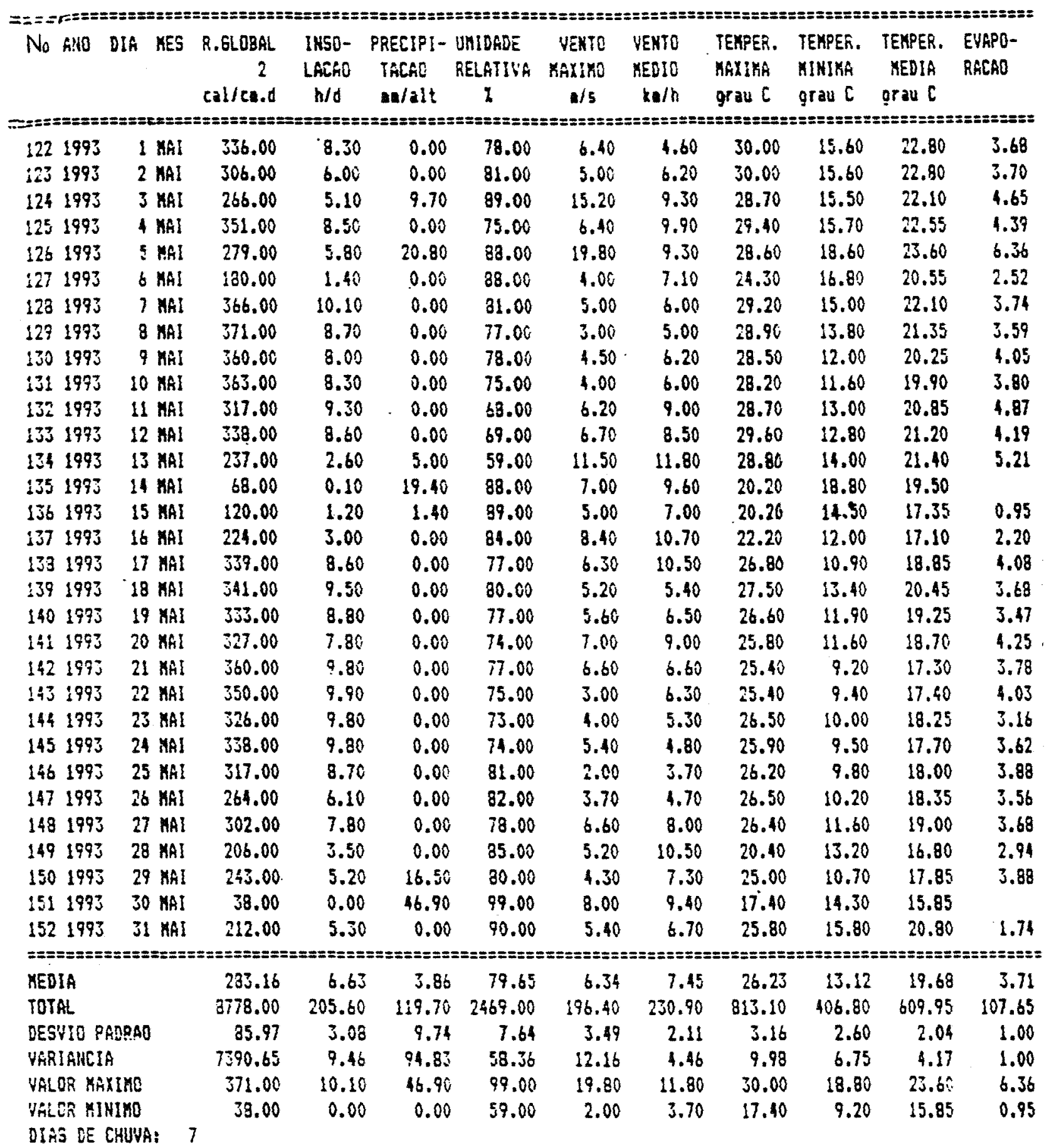


Apêndice I. Dados meteorológicos, obtidos durante o periodo experimental, referente ao periodo de Janeiro a Junho de 1993 .

\begin{tabular}{|c|c|c|c|c|c|c|c|c|c|c|c|}
\hline No ANC & DIA MES & $\begin{array}{c}\text { R. BLOBAL } \\
2 \\
\text { cal/ce.d }\end{array}$ & $\begin{array}{l}\text { IKSO- } \\
\text { LACAO } \\
h / d\end{array}$ & $\begin{array}{l}\text { PRECIP:- } \\
\text { TKCAÓ } \\
\text { Nolalt }\end{array}$ & $\begin{array}{c}\text { UYIGADE } \\
\text { RELATIVA } \\
\frac{h}{}\end{array}$ & $\begin{array}{c}\text { VEHTO } \\
\text { NAXIKO } \\
\text { s/5 }\end{array}$ & $\begin{array}{l}\text { YEHTO } \\
\text { YEDIO } \\
k=/ h\end{array}$ & $\begin{array}{l}\text { TEXPER. } \\
\text { XAXIYA } \\
\text { öBU E }\end{array}$ & $\begin{array}{l}\text { TEMFER. } \\
\text { HIKIKA } \\
\text { graU C }\end{array}$ & $\begin{array}{l}\text { TEKPER. } \\
\text { KEDIA } \\
\text { graU C }\end{array}$ & $\begin{array}{l}\text { EVAPO- } \\
\text { RACAO }\end{array}$ \\
\hline \multicolumn{12}{|c|}{ 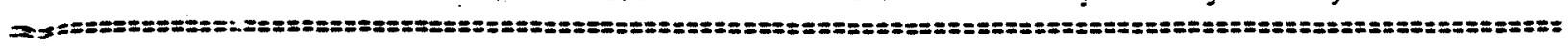 } \\
\hline 2531993 & 1 JUK & 144.00 & 0.60 & $0.0 \%$ & 87.00 & 8.00 & 11.80 & 20.80 & 16.00 & 18.40 & 2.66 \\
\hline 1541993 & 2 JUH & 263.00 & 6.00 & 0.00 & 87.00 & 5.60 & 7.70 & 23.00 & 10.60 & 16.80 & 2.32 \\
\hline 1551993 & J JUK & 272.00 & 8.20 & 0.00 & 85.00 & 4.80 & 8.80 & 25.80 & 12.20 & 19.00 & 2.16 \\
\hline 1561993 & 4 JUK & 312.00 & 8.40 & 12.40 & 81.00 & 9.80 & 11.80 & 27.40 & 13.00 & 20.20 & 3.95 \\
\hline 1571993 & 5 JUH & 113.00 & 1.10 & 1.20 & 95.00 & 4.10 & 5.20 & 22.60 & 16.00 & 19.30 & 0.63 \\
\hline $158 \quad 1993$ & 6 JUH & 248.00 & 6.00 & 0.00 & 89.00 & 4.00 & 4.60 & 25.40 & 17.00 & 21.20 & 2.47 \\
\hline 1591993 & 7 JUN & 273.00 & 6.50 & 0.00 & 87.00 & 1.00 & 5.10 & 27.00 & 14.20 & 20.60 & 2.12 \\
\hline 1601993 & \& JUK & 356.00 & 7.40 & 0.00 & 82.00 & 5.20 & 3.80 & 27.50 & 13.80 & 20.65 & 2.69 \\
\hline 1611993 & 9 JUX & 285.00 & 9.00 & 0.00 & 78.00 & 4.60 & 6.80 & 28.50 & 14.10 & 21.30 & 3.06 \\
\hline 1621793 & so JUK & 113.00 & 0.10 & 2.00 & 92.00 & 4.80 & 9.70 & 21.40 & 17.50 & 19.45 & 1.66 \\
\hline 1631973 & 11 JUN & 143.00 & 1.20 & 0.20 & 87.00 & 4.70 & 12.20 & 17.60 & 13.70 & 16.65 & 1.92 \\
\hline 1641993 & 12 JUK & 300.00 & 9.60 & 0.00 & 80.00 & 9.10 & 12.50 & 23.80 & 13.80 & 18.80 & 3.92 \\
\hline 1651993 & 13 JUK & 332.00 & 9.80 & 0.00 & 78.00 & 8.30 & 9.30 & 24.80 & 10.90 & 17.85 & 3.88 \\
\hline 1661993 & 14 JUH & 329.00 & 9.50 & 0.00 & 77.00 & 4.70 & 7.90 & 24.20 & 8.90 & 16.55 & 3.22 \\
\hline 1671993 & 15 JUK & 293.00 & 7.30 & 0.00 & 73.00 & 5.20 & 8.90 & 24.20 & 7.80 & 16.00 & 2.57 \\
\hline 1631993 & 16 JUN & 318.00 & 8.30 & 0.60 & 73.00 & 11.00 & 10.40 & 24.20 & 10.90 & 17.55 & 3.95 \\
\hline 1691993 & 17 JUK & 228.00 & 1.20 & 9.80 & 76.00 & 11.40 & 8.00 & 24.20 & 12.50 & 18.35 & 2.76 \\
\hline 1701993 & 18 JUK & 30.00 & 0.00 & 21.40 & 97.00 & 6.00 & 12.00 & 16.20 & 14.60 & 15.40 & 1.59 \\
\hline 1711993 & 19 JUK & 284.00 & 6.50 & 0.00 & 83.00 & 2.00 & 5.10 & 20.60 & 11.90 & 16.25 & 2.15 \\
\hline 1721993 & $20 \mathrm{JUK}$ & 288.00 & 6.40 & 0.00 & 85.00 & 2.40 & 4.80 & .21 .50 & 6.10 & 13.80 & 1.58 \\
\hline 1731993 & $21 \mathrm{dUK}$ & 312.00 & 7.60 & 0.00 & 80.00 & 2.50 & 6.50 & 25.60 & 5.50 & 15.55 & 2.57 \\
\hline 1741993 & 22 JUK & 312.00 & 9.70 & 0.00 & 78.00 & 3.50 & 7.50 & 27.00 & 7.90 & 17.15 & 2.55 \\
\hline 1751993 & $23 \mathrm{JUK}$ & 302.00 & 8.90 & 0.00 & 80.00 & 4.80 & 7.40 & 26.50 & 9.40 & 17.95 & 3.08 \\
\hline 1761993 & 24 JUN & 314.00 & 9.60 & 0.00 & 73.00 & 4.50 & 9.20 & 27.40 & 10.10 & 18.75 & 3.84 \\
\hline 1771995 & $25 \mathrm{JUH}$ & 300.00 & 9.20 & 0.00 & 76.00 & 2.50 & 6.00 & 27.60 & 10.00 & 18.30 & 2.48 \\
\hline $178199 j$ & 26 JUK & 321.00 & 8.50 & 0.00 & 75.00 & 5.90 & 8.00 & 26.80 & 9.20 & 18.00 & 3.48 \\
\hline$i 791793$ & 27 JUK & 332.00 & 9.20 & 0.00 & 70.00 & 6.70 & 10.50 & 26.80 & 9.60 & 18.20 & 3.98 \\
\hline 1801993 & 28 JUצ & 314.00 & 9.50 & 0.00 & 67.00 & 5.80 & 8.10 & 27.10 & 9.40 & 18.25 & 3.80 \\
\hline 1811983 & 27 JUK & 248.00 & 6.80 & 0.00 & 67.00 & 4.70 & 7.10 & 27.30 & 9.80 & 18.55 & 2.22 \\
\hline 1821973 & 30 JUK & 227.00 & $4.9 \hat{v}$ & 0.00 & 81.00 & 3.10 & 7.50 & 26.80 & 12.80 & 19.80 & 2.39 \\
\hline \multicolumn{12}{|c|}{ 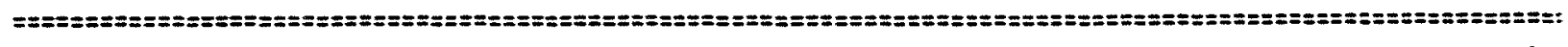 } \\
\hline KEDIA & & 263.73 & 6.57 & 1.57 & 80.77 & 5.37 & 8.31 & 24.72 & 11.64 & 18.18 & 2.74 \\
\hline TOTAL & & $79: 2.00$ & 197.00 & 47.00 & 2423.00 & 161.00 & 247.20 & 741.60 & 349.20 & 545.40 & 82.25 \\
\hline DESVIO PA & ADRAO & 77.38 & 3.20 & 4.62 & 7.37 & 2.52 & 2.28 & 2.87 & 3.03 & 1.76 & 0.83 \\
\hline VHRIAHCIA & & 5928.00 & 10.26 & 21.32 & 54.31 & 6.34 & 5.20 & 2.26 & 9.19 & 3.09 & 0.69 \\
\hline 'VALOR KAX & Ximo & 356.00 & 9.80 & 21.40 & 97.00 & 11.40 & 12.50 & 28.50 & 17.50 & 21.30 & 3.98 \\
\hline $\begin{array}{l}\text { WHLOR X:K } \\
\text { DIAS DE E }\end{array}$ & $\begin{array}{l}\text { HINO } \\
\text { CHUYA: }\end{array}$ & 30.00 & 0.00 & 0.00 & 67.00 & 1.00 & 4.60 & 16.20 & 5.50 & 13.80 & 0.63 \\
\hline
\end{tabular}


Apêndice II. Valores médios das caracteristicas agronômicas estudadas (média de três repetiçóes) em cultivares de mitho de diferentes ciclos $(c 1=$ normal; $c 2=$ precoce e $c 3=$ superprecoce), equatro niveis de nitrogênio $(\mathrm{NO}=0 \mathrm{~kg} / \mathrm{ha} ; \mathrm{N} 1=50 \mathrm{~kg} / \mathrm{ha} ; \mathrm{N} 2=100 \mathrm{~kg} / \mathrm{ha}$ e N3 = $150 \mathrm{~kg} / \mathrm{ha}$ ). Piracicaba, SP, 1993.

\begin{tabular}{|c|c|c|c|c|c|c|}
\hline $\begin{array}{c}\text { Trata- } \\
\text { mentos }\end{array}$ & $\begin{array}{l}\text { Altura } \\
(\mathrm{cm})\end{array}$ & IAF & $\begin{array}{l}\text { No Es- } \\
\text { piga( }{ }^{(1)} \\
\text { Planta }\end{array}$ & $\begin{array}{l}\text { Compri- } \\
\text { mento de } \\
\text { espige } \\
\text { (cm) }\end{array}$ & $\begin{array}{l}\text { Peso de } \\
\text { Espiga } \\
\text { (kg/ha) }\end{array}$ & $\begin{array}{c}\text { Peso de } \\
\text { grăo } \\
\text { (kg/ha) }\end{array}$ \\
\hline CINO & 182 & 2,65 & 1,00 & 15,4 & 7.432 & 4.029 \\
\hline C1N1 & 197 & 2,85 & 1,00 & 16,5 & 7.891 & 4.129 \\
\hline C1N2 & 203 & 3,25 & 1,67 & 17,0 & 8.062 & 4.173 \\
\hline C1N3 & 210 & 3,49 & 2,00 & 17.7 & 8.784 & 4.396 \\
\hline $\mathrm{C} 2 \mathrm{NO}$ & 162 & 2,31 & 1,00 & 14,8 & 10.269 & 5.114 \\
\hline $\mathrm{c} 2 \mathrm{~N} 1$ & 179 & 2,69 & 1,33 & 16,2 & 11.716 & 6.448 \\
\hline $\mathrm{C} 2 \mathrm{~N} 2$ & 185 & 3,03 & 1,67 & 17,6 & 12.077 & 6.690 \\
\hline $\mathrm{c} 2 \mathrm{~N} 3$ & 187 & 3,13 & 2,00 & 17,8 & 12.144 & 6.848 \\
\hline C3NO & 178 & 1.99 & 1,00 & 14,5 & 3.816 & 2.576 \\
\hline c3N1 & 181 & 2,15 & 1,33 & 15,6 & 3.932 & 2.736 \\
\hline C3N2 & 184 & 2,38 & 1,67 & 15,4 & 4.531 & 3.030 \\
\hline c3N3 & 194 & 3,07 & 1,67 & 15,6 & 4.891 & 3.148 \\
\hline
\end{tabular}

Cultivares ( $\mathrm{c} 1=$ normal; $\mathrm{c} 2=$ precoce; $\mathrm{c} 3=$ superprecoce) .

Doses de nitrogênio $(\mathrm{NO}=\mathrm{O} \mathrm{kg} / \mathrm{ha} ; \mathrm{N1}=50 \mathrm{~kg} / \mathrm{ha} ; \mathrm{N} 2=100 \mathrm{~kg} / \mathrm{ha}$ e $\mathrm{N} 3=$ $150 \mathrm{~kg} / \mathrm{ha}$ )

(1) Os dados foram transformados para $\sqrt{x / 100}$, para obtenção da equação de regressão. 


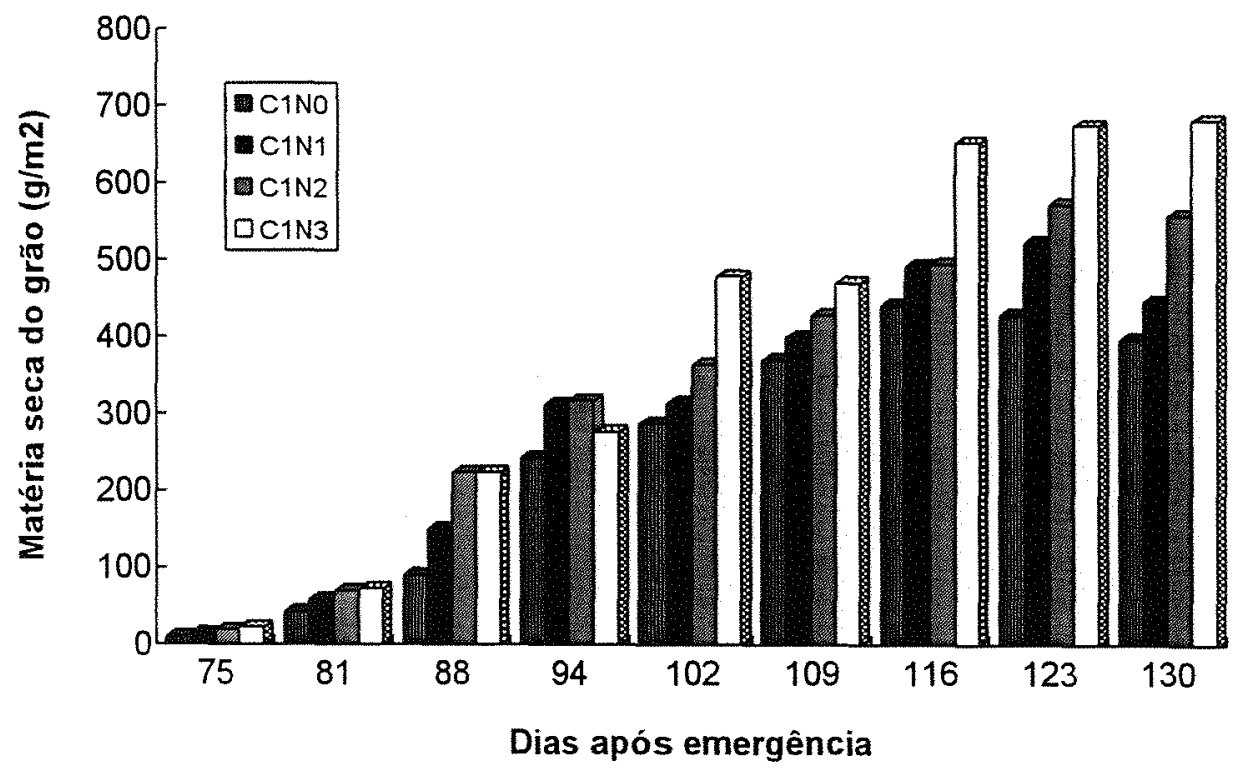

Apêndice III. Valores médios da matéria seca do grão (média de seis plantas) em cultivar de milho de ciclo normal (c1= XL380) e quatro níveis de nitrogênio. Piracicaba, SP. 1993. 


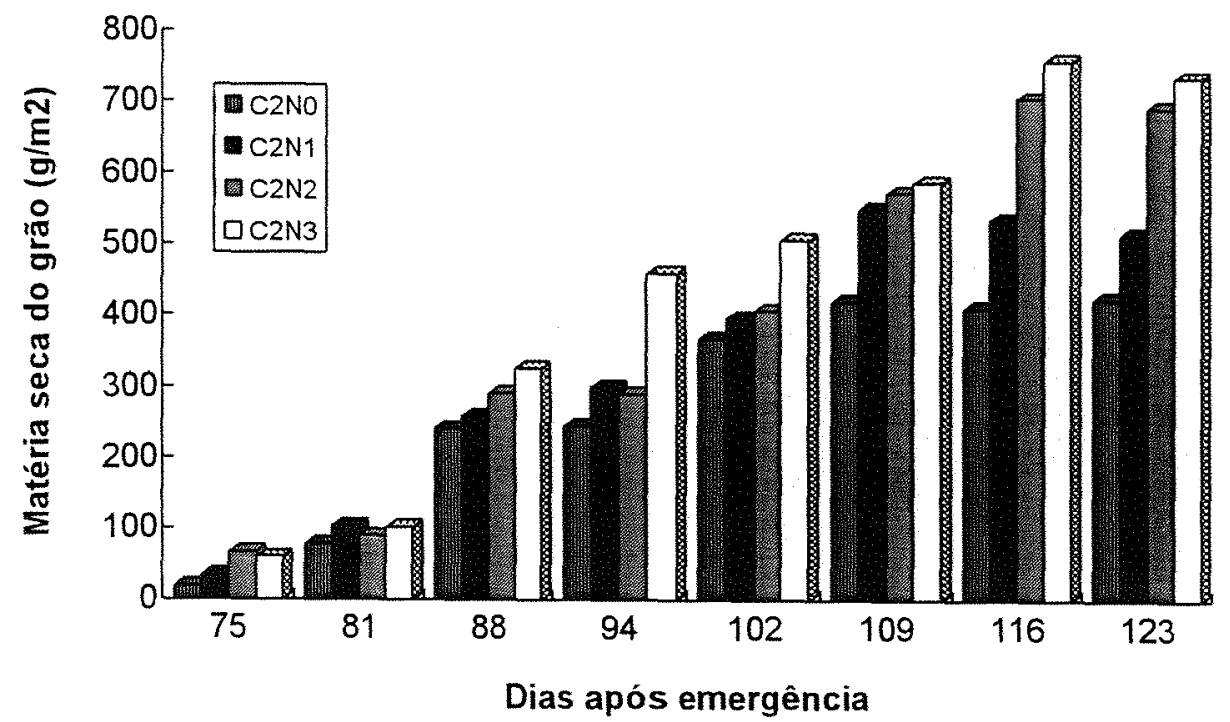

Apêndice IV. Valores médios da matéria seca do grão (média de seis plantas) em cultivar de milho de ciclo normal (c2 = BR201) e quatro níveis de nitrogênio. Piracicaba, SP. 1993. 


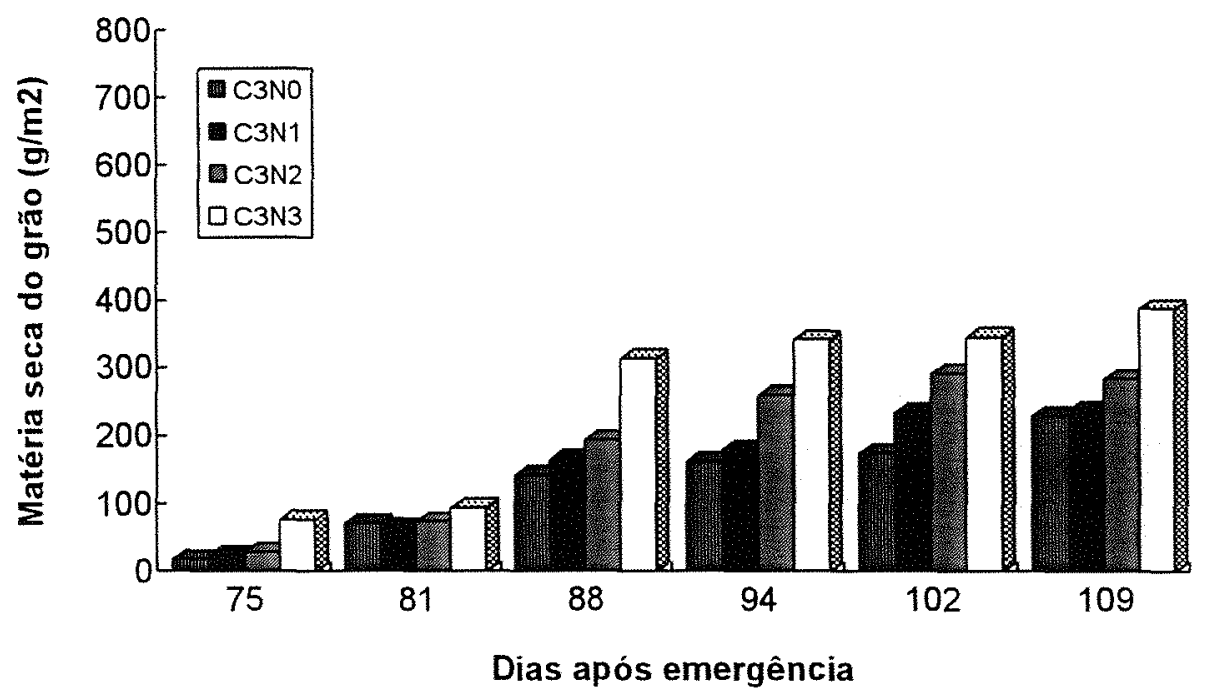

Apêndice $V$. Valores médios da matéria seca do grão (média de seis plantas) em cultivar de milho de ciclo superprecoce $(c 3=$ P3072) e quatro niveis de nitrogênio. Piracicaba, SP. 1993. 